INSTITUTO HISTÓRICO E GEOGRÁFICO BRASILEIRO

José Damião Rodrigues

\title{
REFORMAS E ILUMINISMO NO MUNDO ATLÂNTICO: O CASO PORTUGUÊS
}

RODRIGUES, José Damião

REFORMAS E ILUMINISMO NO MUNDO ATLÂNTICO: O CASO PORTUGUÊS

R. IHGB, Rio de Janeiro, a. 182(486): 101-136, mai./ago. 2021

Rio de Janeiro

mai./ago. 2021 


\title{
REFORMAS E ILUMINISMO NO MUNDO ATLÂNTICO: O CASO PORTUGUÊS ${ }^{1}$
}

\author{
REFORMS AND ENLIGHTENMENT IN THE ATLANTIC \\ WORLD: THE PORTUGUESE CASE
}

José DAMIÃo RoDRIGUES ${ }^{2}$

\begin{abstract}
Resumo:
Uma das questões que tem merecido mais atenção por parte de diferentes historiografias tem como pano de fundo cronológico um longo século XVIII, embora com maior incidência cronológica nos meados e na segunda metade de Setecentos, e respeita a eventual relação entre os projectos e as práticas reformistas, por um lado, e o corpo de ideias a que se chamou Iluminismo, por outro. No caso português, o reinado de D. José I é geralmente apresentado como uma etapa decisiva das reformas ilustradas, sendo esse período perspectivado mais em termos de ruptura do que de continuidade, buscando-se naquela as marcas da "modernidade" do Iluminismo. Neste texto, tendo como pano de fundo o mundo atlântico e, em particular, o espaço português, pretendemos discutir a relação, por vezes demasiado apressada, entre reformas setecentistas e Iluminismo, nomeadamente as que são atribuídas ao Secretário de Estado Sebastião José de Carvalho e Melo, e os limites dessas mesmas reformas.
\end{abstract}

Palavras-chave: Iluminismo; Reformas; Portugal; Império; Marquês de Pombal.

\section{Abstract:}

One of the issues that has received increasingly more attention from different historiographies has a long eighteenth century as its chronological frame, and, more specifically, the period from the mid to the end of the 18 th century. It refers to the possible relationship between projects and reformist practices, on the one hand, and the set of ideas under the label of Enlightenment, on the other. In the Portuguese case, the reign of $D$. José I is generally presented as a decisive stage of the enlightened reforms. The period is viewed more in terms of rupture than of continuity, the former bringing with it signs of "modernity" of the Enlightenment. From the perspective of the Atlantic world and, in particular, of the Portuguese Atlantic world, we discuss in the paper the relationship that is sometimes hastily made between eighteenth-century reforms and the Enlightenment, especially those attributed to the Secretary of State Sebastião José de Carvalho and Melo, and the limits of the reforms.

Keywords: Enlightenment; reforms; Portugal; empire; Marquis of Pombal.

\section{A emergência da modernidade configura-se como um dos territó-} rios mais instigantes e percorridos pelas ciências humanas e, neste quadro,

1 - Este texto constitui a base da Conferência de Abertura proferida no dia 7 de Dezembro de 2020 por ocasião do evento online O Brasil e o Mundo Atlântico: entre a modernidade e a contemporaneidade, organizado pelo NEMAt - UFPE (Núcleo de Estudos do Mundo Atlântico), LABEEM - UESB (Laboratório de Estudos da Escravidão e das Mestiçagens), NESEM-UFAL (Núcleo Escravidão e Sociedade na Época Moderna) e NEIC - UFRPE (Núcleo de Estudos Império Coloniais), 7 a 10 de Dezembro de 2020. 2 - Doutor em História. Professor Associado da Faculdade de Letras da Universidade de Lisboa e investigador integrado do Centro de História da Universidade de Lisboa (CH-ULisboa). Director do Doutoramento em História Marítima e Director do Mestrado em Estudos Brasileiros. E-mail: josedamiaorodrigues@campus.ul.pt. 
os historiadores têm contribuído para os debates que se vêm desenvolvendo desde o século XIX buscando as raízes dessa mesma modernidade, da politização das sociedades tradicionais e da génese do "espaço público"”". Uma questão que tem merecido a atenção continuada por parte de diferentes historiografias tem como pano de fundo cronológico um longo século XVIII, embora com maior incidência cronológica nos meados e na segunda metade de Setecentos, e respeita a eventual relação entre os projectos e as práticas reformistas, por um lado, e o corpo de ideias a que se chamou Iluminismo, por outro. Com efeito, é possível identificar um corpus de obras relevantes que, tendo como pano de fundo espacial o mundo europeu e os seus prolongamentos ultramarinos, sobretudo nos espaços atlântico e americano, procura responder às interrogações suscitadas pela dinâmica histórica global, sem que exista, todavia, um consenso quanto aos resultados. Em particular, neste corpus historiográfico que continua em crescimento, busca-se identificar e avaliar as possíveis relações que se podem estabelecer entre reformismo e iluminismo e entre iluminismo e modernidade ou modernização e quais foram as forças operativas em presença ${ }^{4}$.

3 - A obra clássica sobre este assunto é de HABERMAS, Jürgen. A transformação estrutural da esfera pública: investigações sobre uma categoria da sociedade burguesa. Lisboa: Fundação Calouste Gulbenkian, 2013 [edição original: 1962]. Para o contexto que aqui nos interessa, assinalamos a obra de GUERRA, François-Xavier, LEMPÉRIÈRE, Annick et al.. Los espacios públicos en Iberoamérica: ambigüedades y problemas. Siglos XVIII-XIX. México: Centro francés de estudios mexicanos y centroamericanos, Fondo de Cultura Económica, 1998.

4 - Sobre a "modernidade política", veja-se o estudo já clássico de GUERRA, François-Xavier. Modernidad e independencias. Ensayos sobre las revoluciones hispánicas. Madrid: Fundación Mapfre, 1992. Também do mesmo autor, LEMPÉRIĖRE, Annick e LOMNÉ, Georges (comp.). Figuras de la modernidad: Hispanoamérica siglos XIX-XX. Bogotá: Universidad Externado de Colombia-Taurus, 2012. Para uma leitura complementar do problema da "modernidade" e da sua relação com as reformas nas Américas ibéricas, ver ZERMEÑO PADILLA, Guillermo. História, experiência e modernidade na América ibérica, 1750-1850. Almanack Braziliense. Guarulhos: n. ${ }^{\circ}$ 7, p. 5-46, Maio 2008. Sobre o conceito de "modernidade", a sua complexidade e o uso do vocábulo no contexto da emergência do liberalismo e das novas nações em começos de Oitocentos, ver QUIJADA, Mónica. Sobre 'nación', 'pueblo', 'soberanía' y otros ejes de la modernidade en el mundo hispânico. In: RODRÍGUEZ O., Jaime E. (coord.). Las nuevas naciones: España y México 1800-1850. Madrid: Fundación Mapfre, 2008, p. 19-51. 
Para muitos historiadores europeus ou do hemisfério americano, tratava-se inicialmente de compreender em que medida o esforço reformista das monarquias europeias se traduzira na reorganização política e administrativa do reino e, depois, das Américas, cooptando ou não as elites dos diversos territórios americanos, e como é que este investimento podia ter conduzido, num nexo causal, a uma transformação social, às independências oitocentistas e à emergência dos Estados-nação. Para os defensores desta linha de raciocínio, existe uma inquestionável relação entre pensamento ilustrado, reformismo, identidade protonacional e, por fim, independência. O ideário iluminista ou, se se preferir, da "modernidade ilustrada" teria constituído assim o fermento intelectual a partir do qual as distintas elites das periferias imperiais americanas começaram a pensar a sua diferença. Presume-se, pois, que antes de 1808, nas Américas espanhola e portuguesa, a afirmação identitária seria de matriz ilustrada e, paradoxalmente, que uma clivagem entre a monarquia e as elites se deu em boa medida como uma reacção às reformas ilustradas do centro, que romperam o pacto entre a monarquia e as elites locais, visando impor um maior controlo sobre os territórios imperiais, objectivo visível, por exemplo, na criação das intendências, um processo que conheceu um ritmo mais intenso a partir de 1776 . O reinado de Carlos III, período em que se assistiu a uma importante expansão demográfica e económica, surge neste quadro como o exemplo mais acabado de um período durante o qual se aplicou um "programa" reformistas.

As reformas idealizadas e implementadas no império espanhol, as reformas bourbónicas, são de tal forma centrais no quadro das historiografias ibero-americanas e das historiografias que se dedicam ao estudo da monarquia espanhola no século XVIII que constituem mesmo uma categoria analítica própria ${ }^{6}$. A perspectiva de uma certa "ortodoxia" his-

5 - Para o império espanhol, vejam-se as obras de STEIN, Stanley J. e STEIN, Barbara Hadley. Silver, Trade, and War: Spain and America in the Making of the Early Modern Europe. Baltimore: Johns Hopkins University Press, 2000; Idem. Apogee of Empire: Spain and New Spain in the Age of Charles III, 1759-1789. Baltimore: Johns Hopkins University Press, 2003; Idem. Edge of Crisis: War and Trade in the Spanish Atlantic, 1789-1808. Baltimore: Johns Hopkins University Press, 2009.

6 - Cf. SÁNCHEZ SANTIRÓ, Ernest. Las reformas borbónicas como categoría 
toriográfica vigente nas décadas de 1970 e 1980 pode ser encontrada na formulação de John Lynch, que falou da "desconstrução do Estado criollo" e da "desamericanização da América": por um lado, ocorreu uma vaga migratória de peninsulares a partir de 1760 e, por outro, existia uma manifesta antipatia do Secretário de Estado do Despacho Universal de Índias José de Gálvez contra os criollos, criando-se, assim, as condições para a génese de uma tomada de consciência das diferenças que existiam entre Espanha e o império e o desenvolvimento de uma identidade nacional criolla ${ }^{7}$. E como se estabeleceu, com frequência, um vínculo entre iluminismo e protoliberalismo e entre este e modernidade, a orientação ideológica parece clara: as novas nações, quando nasceram, já eram modernas. Não pensemos, porém, que esta formulação ideológica acerca da etnogénese nacional se pode encontrar apenas em algumas obras mais datadas. Pelo contrário, uma afirmação inequívoca desta filiação, ou seja, que o novo Estado-nação americano saiu das reformas setecentistas, no caso bourbónicas, está presente em edições bem recentes ${ }^{8}$.

Este é um debate historiográfico em aberto, inacabado, e que mobiliza interpretações dissonantes. Nas últimas décadas, as contribuições oriundas da chamada Atlantic history enriqueceram as perspectivas existentes $^{9}$, introduzindo uma escala de análise de maior fôlego e, na linha

de análisis en la historiografía institucional, económica y fiscal sobre Nueva España: orígenes, implantación y expansión. Historia Caribe. Vol. XI, n. ${ }^{\circ}$ 29, p. 19-51, JulhoDezembro 2016.

7 - Cf. "John Lynch", in CHUST, Manuel (ed.). Las independencias iberoamericanas en su laberinto. Controversias, cuestiones, interpretaciones. Valencia: Universitat de València, 2010, p. 241-249.

8 - "El efecto del ensayo reformista en la Nueva España fue contundente. En apenas cuatro décadas, el perfil del virreinato adoptó su rostro maduro, preludio de la futura nación." Cf. FRANCO, María Teresa. Presentación. In: ROMÁN GUTIÉRREZ, José Francisco (ed.). Las reformas borbónicas y el nuevo orden colonial. México: Instituto Nacional de Antropología e Historia, 2020, sem n. ${ }^{\circ}$ de página [edição electrónica].

9 - Para uma apresentação dos objectivos e sínteses do "estado da arte" da Atlantic history, ver BAILYN, Bernard. Atlantic History: Concept and Contours. Cambridge, Mass.London: Harvard University Press, 2005; GREENE, Jack P. e MORGAN, Philip D. (eds.). Atlantic History: A Critical Appraisal. New York: Oxford University Press, 2009; BAILYN, Bernard e DENAULT, Patricia L. (eds.). Soundings in Atlantic History: Latent Structures and Intellectual Currents, 1500-1830. Cambridge, Ma.-London University Press: Harvard, 2009; CANNY, Nicholas e MORGAN, Philip (eds.). The Oxford Hand- 
das connected histories ou entangled histories, o potencial da dimensão comparativa entre impérios e territórios cujas histórias se interpenetravam $^{10}$. Por outro lado, convirá recordar que este debate ocorre a par de todo um profundo trabalho de revisão e reavaliação historiográficas que se vem operando desde a década de 1980 no que diz respeito à relação entre monarquias absolutas e Iluminismo, por um lado, e ao conteúdo e uso de categorias históricas e analíticas como "Iluminismo" e "despotismo esclarecido" ou "despotismo iluminado" 11 ". Com efeito, embora

book of the Atlantic World: 1450-1850. Oxford: Oxford University Press, 2011; PRIOR, David. After the Revolution: An Alternative Future for Atlantic History. History Compass. 12/3, p. 300-309, 2014; MILLER, Joseph C. (ed.). The Princeton Companion to Atlantic History. Princeton and Oxford: Princeton University Press, 2015. Para as críticas dirigidas à Atlantic history norte-americana ou anglo-saxónica, ver, entre outros, COCLANIS, Peter A.. Drang Nach Osten: Bernard Bailyn, the World-Island, and the Idea of Atlantic History. Journal of World History, vol. 13, n. ${ }^{\circ}$ 1, p. 169-182, 2002; MORELLI, Federica e GÓMEZ, Alejandro E.. La nueva Historia Atlántica: un asunto de escalas. Nuevo Mundo Mundos Nuevos [online], n. ${ }^{\circ}$ 6, 2006. Disponível em: http://nuevomundo.revues.org/ document2102.html. Acesso em: 20.06.17; SCHAUB, Jean-Frédéric. The Case for a Broader Atlantic History. Nuevo Mundo Mundos Nuevos [online]. Coloquios, 2012. Disponível em: http://nuevomundo.revues.org/63478. Acesso em: 31.12.14. Para uma tentativa de articulação entre a Atlantic history e a global history, ver CAÑIZARES-ESGUERRA, Jorge e SEEMAN, Erik. The Atlantic in Global History, 1500-2000. Upper Saddle River, NJ: Prentice Hall, 2006. Para uma crítica "atlântica" da global history, ver ZUÑIGA, Jean-Paul. L'Histoire impériale à l'heure de l' «histoire globale». Une perspective atlantique. Revue d'histoire moderne et contemporaine, n. ${ }^{\circ}$ 54-4bis, p. 54-68, 2007/5.

10 - Cf. ADELMAN, Jeremy. Sovereignty and Revolution in the Iberian World. Princeton and Oxford: Princeton University Press, 2006; TORTAROLO, Edoardo. Eighteenthcentury Atlantic history old and new. History of European Ideas. 34, p. 369-374, 2008; PAQUETTE, Gabriel (ed.). Enlightened Reform in Southern Europe and its Atlantic Colonies, c. 1750-1830. Farnham and Burlington, VT.: Ashgate, 2009; e RODRIGUES, José Damião (coord.). O Atlântico Revolucionário: circulação de ideias e de elites no final do Antigo Regime. Ponta Delgada: CHAM, 2012. Para uma apresentação geral das perspectivas das connected histories para o caso dos impérios ibéricos, ver as contribuições de SUBRAHMANYAM, Sanjay. Holding the World in Balance: The Connected Histories of the Iberian Overseas Empires, 1500-1640. American Historical Review, Vol. 112, n. ${ }^{\circ}$ 5, p. 1359-1385, December 2007; SUBRAHMANYAM, Sanjay. Sobre comparaciones y conexiones: notas sobre el estudio de los imperios ibéricos de Ultramar, 1490-1640. In: CHARTIER, Roger e FEROS, Antonio (dir.). Europa, América y el mundo: tiempos históricos. Madrid-Barcelona: Fundación Rafael del Pino-Fundación Carolina-Colegio Libre de Eméritos-Marcial Pons, 2006, p. 239-262. Para a perspectiva das entangled histories, ver American Historical Review, vol. 112, n. ${ }^{\circ}$ 3, June 2007: “AHR Forum. Entangled Empires in the Atlantic World".

11 - Sobre os problemas colocados pelo uso da categoria "despotismo iluminado", expressão cunhada e usada já no século XVIII, ver, entre outros, as observações de 
sem conquistarem a unanimidade entre os historiadores, novos ângulos de análise modificaram o mapa conceptual do Iluminismo, chamando a atenção para a necessidade de se equacionarem os diferentes contextos nacionais e regionais, o envolvimento diferenciado dos múltiplos corpos e actores sociais nos processos estudados e a existência de vários centros de gravidade intelectual na Europa do século XVIII, o que se traduzia numa polifonia de vozes e de sentidos, em suma, numa multiplicidade de Iluminismos, em cujo contexto a França surge afinal como o contraexemplo face às descentragens geográfica e cronológica operadas ${ }^{12}$. Neste

INGRAO, Charles. The Problem of "Enlightened Absolutism" and the German States. The Journal of Modern History. Vol. 58, Supplement: Politics and Society in the Holy Roman Empire, 1500-1806, p. S161-S180, Dezembro 1986; BLACK, Jeremy. La Europa del siglo XVIII 1700-1789. Madrid: Akal, 1997 [edição original: 1990], p. 395-396 e 451456; e PAQUETTE, Gabriel B.. Empire, Enlightenment and Regalism: New Directions in Eighteenth-century Spanish History. European History Quarterly, Vol. 35 (1), p. 107-117. Para a formulação original da expressão "despotismo iluminado", ver BEALES, Derek. Enlightenment and Reform in Eighteenth-century Europe. London-New York: I. B. Tauris, 2005, p. 49-53.

12 - De entre uma vasta bibliografia, citemos apenas alguns livros e artigos mais recentes, remetendo para a bibliografia aí indicada: KIRK, Linda. The Matter of Enlightenment. The Historical Journal, Vol. 43, n. ${ }^{\circ}$ 4, p. 1129-1143, 2000; BRADLEY, James E. e VAN KLEY, Dale K. (ed.). Religion and Politics in Enlightenment Europe. Notre Dame: The University of Notre Dame Press, 2001; PORTER, Roy. Enlightenment: Britain and the Creation of the Modern World. London: Penguin Books, 2001; MCMAHON, Darrin M.. Enemies of the Enlightenment: The French Counter-Enlightenment and the Making of Modernity. Oxford-New York: Oxford University Press, 2001; KORS, Alan Charles (ed.). Encyclopedia of the Enlightenment. Oxford: Oxford University Press, 2003, 4 vols.; HIMMELFARB, Gertrude. The Roads to Modernity: The British, French, and American Enlightenments. New York: Knopf, 2004; OUTRAM, Dorinda. The Enlightenment. $2^{\mathrm{a}}$ ed., Cambridge: Cambridge University Press, 2005 [edição original: 1995]; MCMAHON, Darrin M. e HANLEY, Ryan. The Enlightenment: Critical Concepts in Historical Studies. London: Routledge, 2009, 5 vols.; AHR Forum - New Perspectives on the Enlightenment. The American Historical Review, Vol. 115, n. ${ }^{\circ}$ 5, p. 1340-1435, Dezembro 2010; SCHMIDT, James. Misunderstanding the Question: 'What Is Enlightenment?': Venturi, Habermas, and Foucault. History of European Ideas, 37, p. 43-52, 2011; SCHMIDT, James. Enlightenment as Concept and Context. Journal of the History of Ideas, Vol. 75, n. ${ }^{\circ}$ 4, p. 677-685, October 2014; LAVAERT, Sonja e SCHRÖDER, Winfried (eds.). The Dutch Legacy: Radical Thinkers of the 17th Century and the Enlightenment. Leiden-Boston: Brill, 2016; LILTI, Antoine. L'héritage des Lumières. Ambivalences de la modernité. Paris: Éditions de 1'EHESS, 2019. Neste contexto de reequacionamento do Iluminismo, importa ainda pensar para além da Europa como forma de evitar os perigos do eurocentrismo. A este respeito assinalamos a contribuição de FOURCADE, Marie e ŽUPANOV, Ines G. (dir.). L'Inde des Lumières. Discours, histoire, savoirs (XVII ${ }^{e}-X I X^{e}$ siècle). Paris: 
contexto, e pela ambição e relevância das suas obras, merecem destaque os nomes de J. G. A. Pocock ${ }^{13}$ e de Jonathan I. Israel ${ }^{14}$.

Ainda a este respeito, e numa breve nota, é justo recordar que, precisamente no começo dos anos oitenta, Luís Reis Torgal, em "Nota Introdutória" ao número da Revista de História das Ideias dedicado ao marquês de Pombal, após breve exposição sobre a perspectiva de alguns historiadores, como François Bluche (1925-) e Matthew Anderson (19222006), concluía já pela diversidade de casos, afirmando então que "os «despotismos esclarecidos» ou «absolutismos esclarecidos»- expressões que os historiadores continuam, apesar de tudo, a usar - estão cheios de incoerências ${ }^{15}$ ". Não obstante a desconfiança e a hesitação que pode-

Édition de l'École des hautes études en sciences sociales, 2013.

13 - Cf. POCOCK, J. G. A.. Barbarism and Religion. Cambridge: Cambridge University Press, 6 vols., 1999-2015. Face à sua importância, o impressionante tour de force de J. G. A. Pocock foi objecto de análise em número do Journal of the History of Ideas, vol. 77, n. ${ }^{\circ}$ 1, January 2016: Symposium on J. G. A. Pocock's Barbarism and religion. Sobre as formulações teóricas da chamada "Cambridge School of Intellectual History", que defende a correcta contextualização histórica dos autores estudados e da respectiva produção, além da obra de J. G. A. Pocock, são de consulta obrigatória os estudos de Quentin Skinner. Para uma introdução, ver SKINNER, Quentin. Visions of Politics, vol. 1: Regarding Method. Cambridge: Cambridge University Press, 2002. Para uma síntese destas formulações, ver BRETT, Annabel. Que é a história intelectual hoje?. In: CANNADINE, David (coord.). Que é a história hoje? . Lisboa: Gradiva, 2006 [edição original: 2002], p. 151-172.

14 - Cf. ISRAEL, Jonathan I.. Radical Enlightenment: Philosophy and the Making of Modernity, 1650-1750. Oxford: Oxford University Press, 2001; Enlightenment Contested: Philosophy, Modernity, and the Emancipation of Man 1670-1752. Oxford: Oxford University Press, 2006; A Revolution of the Mind: Radical Enlightenment and the Intellectual Origins of Modern Democracy. Princeton: Princeton University Press, 2010; Democratic Enlightenment: Philosophy, Revolution, and Human Rights 1750-1790. Oxford: Oxford University Press, 2011; Revolutionary Ideas: an Intellectual History of the French Revolution from the Rights of Man to Robespierre. Princeton: Princeton University Press, 2014. Contrariamente à obra de J. G. A. Pocock, a visão ou revisão de Jonathan I. Israel tem sido recebida com mais críticas e resistências. De entre estas, indicamos LA VOPA, Anthony J.. Historiographical Reviews. A New Intellectual History? Jonathan Israel's Enlightenment. The Historical Journal. Vol. 52, n. ${ }^{\circ}$ 3, p. 717-738, 2009; MCMAHON, Dar-

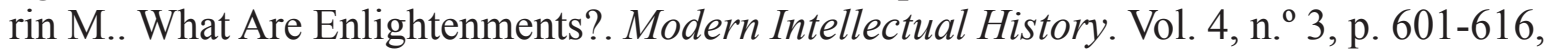
2007. Para uma síntese, ver MUNCK, Thomas. The Enlightenment as Modernity: Jonathan Israel's Interpretation Across Two Decades. Reviews in History. Review n. ${ }^{\circ} 2039$, Dezembro 2016. Disponível em: https://reviews.history.ac.uk/review/2039. Acesso em: 4.12.07; DOI: 10.14296/RiH/2014/2039.

15 - Cf. TORGAL, Luís Reis. Nota introdutória. Acerca do significado do Pombalismo. 
mos detectar em alguns historiadores quanto ao uso das citadas expressões, certo é que as mesmas ainda encontram defensores, como Gabriel Paquette, se bem que alertando para a necessidade de se reavaliar o que foi o Iluminismo, pensando este mais como "a series of communicative practices $^{16}$ '.

Por outro lado, importa lembrar que, em anos mais próximos, graças a um trabalho porfiado, com recurso a documentação de arquivo - e não somente a diplomas e textos "programáticos" -, novos ângulos de análise, libertos de modelos herdados da historiografia liberal e nacionalista - o "paradigma estadualista", de que falou António Manuel Hespanha17 -, permitiram uma significativa renovação historiográfica destas questões. Em primeiro lugar, importa sublinhar a recusa de uma "visão progressiva" da história, ou seja, de uma interpretação que considerava existir um progresso linear e uma lógica de modernização no tocante aos programas reformistas e à recusa das dicotomias introduzidas pelo liberalismo ${ }^{18}$. Depois, além de recuarem a cronologia das reformas setecentistas, as mais recentes contribuições têm sublinhado a importância da negociação e das tensões entre as monarquias e as elites; apontado as hesitações dos reformadores; identificado os limites do poder monárquico e dos reformismos setecentistas, que se confrontavam com o ordenamento jurídico e social do Antigo Regime; e, por fim, denunciado as insuficiências das interpretações teleológicas, nomeadamente no que respeita à conjuntura da viragem do século XVIII para o século XIX e ao início dos processos

\footnotetext{
Revista de História das Ideias. Coimbra: vol. 4: O Marquês de Pombal e o seu tempo. Número Especial no $2^{\circ}$ Centenário da sua morte, 1982-1983, Tomo I, p. 7-17, maxime p. 10 para a citação.

16 - Cf. PAQUETTE, Gabriel. The reform of the Spanish empire in the age of Enlightenment. In: ASTIGARRAGA, Jesús (ed.). The Spanish Enlightenment revisited. Oxford: Voltaire Foundation, p. 149-167, 2015, maxime p. 151-153.

17 - Para uma exposição e crítica do que considerou ser o "paradigma estadualista", ver HESPANHA, António Manuel. Para uma teoria da história institucional do Antigo Regime. In: HESPANHA, António Manuel (org.). Poderes e instituições na Europa do Antigo Regime. Colectânea de textos. Lisboa: Fundação Calouste Gulbenkian, 1984, p. 7-89.

18 - Cf. GUERRA, François-Xavier. Revolución Francesa y revoluciones hispánicas: una relación compleja. In: LEMPÉRIÈRE, Annick e LOMNÉ, Georges (comp.). Figuras de la modernidad: ..., p. 291-327, maxime p. 297-299.
} 
independentistas ${ }^{19}$. Desde logo, as reformas da primeira etapa do reinado de Filipe $\mathrm{V}$ foram integradas numa perspectiva mais alargada; por outro lado, os projectos concebidos para os territórios imperiais foram situados em conjunturas precisas e nos seus contextos específicos, evitando ou tentando evitar a tentação de construir uma narrativa que tivesse em conta o que os historiadores já sabiam acerca dos "futuros do passado", ou seja, de um passado que, para os coevos, era ainda um futuro incerto, por fazer.

Esta sinopse, muito geral, aplica-se também, conforme dissemos, ao caso da monarquia pluricontinental portuguesa. É inegável que os progressos registados nas últimas décadas pelas historiografias portuguesa e brasileira permitiram rever modelos interpretativos, moldados no paradigma da "centralização", e desfazer - ou dar início à tarefa - de mitos e equívocos relativos ao Antigo Regime, quer para o reino, quer para o império português ${ }^{20}$. No entanto, apesar das edições publicadas por ocasião

19 - Ver, entre outros, PORTILLO VALDÉS, José M.. Crisis atlántica. Autonomia e independencia en la crisis de la monarquía hispana. Madrid: Fundación Carolina, Centro de Estudios Hispánicos e Iberoamericanos, Marcial Pons Historia, 2006; PAQUETTE, Gabriel. Enlightenment, Governance, and Reform in Spain and its Empire, 1759-1808. Basingstoke: Palgrave Macmillan, 2008; MORELLI, Federica. La redefinición de las relaciones imperiales: en torno a la relación reformas dieciochescas/independencia en América. Nuevo Mundo Mundos Nuevos [online]. Debates, 2008, colocado online a 17 de Maio de 2008. Disponível em: http://nuevomundo.revues.org/index32942.html; ALBAREDA, Joaquim. El debate sobre la modernidad del reformismos [sic] borbónico. Revista HMiC. N. ${ }^{\circ}$ X, p. 6-18, 2012; GARRIGA, Carlos. Os limites do reformismo bourbônico: a propósito da administração da justiça na América espanhola. Almanack. Guarulhos: n. ${ }^{\circ}$ 6, p. 38-60, 2. ${ }^{\circ}$ semestre de 2013; PEARCE, Adrian J.. The Origins of Bourbon Reform in Spanish South America, 1700-1763. New York: Palgrave Macmillan, 2014; KUETHE, Allan J. e ANDRIEN, Kenneth J.. The Spanish Atlantic World in the Eighteenth Century. War and the Bourbon Reforms, 1713-1796. New York: Cambridge University Press, 2014; EXBALIN, Arnaud. L'ordre urbain à Mexico. Acteurs, règlements et réformes de police (1692-1794). Nuevo Mundo Mundos Nuevos [online], Extratos de teses, colocado online a 11 de Junho de 2015. Disponível em: http://nuevomundo.revues.org/68104. Veja-se ainda o sugestivo ensaio interpretativo de PAQUETTE, Gabriel. Historiographical Reviews. The Dissolution of the Spanish Atlantic Monarchy. The Historical Journal. 52 (1), p. 175-212, 2009.

20 - Entre outros exemplos possíveis, ver FRAGOSO, João; BICALHO, Maria Fernanda e GOUVÊA, Maria de Fátima (org.). O Antigo Regime nos trópicos: a dinâmica imperial portuguesa (séculos XVI-XVIII). Rio de Janeiro: Civilização Brasileira, 2001; e MONTEIRO, Nuno Gonçalo F.; CARDIM, Pedro e CUNHA, Mafalda Soares da (org.). Optima Pars: elites ibero-americanas do Antigo Regime. Lisboa: Imprensa de Ciências 
do duplo centenário da morte do marquês de Pombal $^{21}$ e de relevantes contribuições no campo da história económica e social ${ }^{22}$, um dos períodos que menos tem beneficiado com a renovação historiográfica é, em nosso entender, o reinado josefino, coincidindo com a presença de Sebastião José de Carvalho e Melo nos gabinetes do poder ${ }^{23}$.

De um modo geral, o período pombalino tem sido perspectivado mais em termos de ruptura do que de continuidade, buscando-se naquela as marcas da "modernidade" do Iluminismo. De acordo com esta lógica, e coincidindo praticamente com a ascensão de Sebastião José de Carvalho e Melo, o Iluminismo adquiriu em Portugal uma "feição de Estado", no contexto do "despotismo esclarecido", verificando-se uma aliança entre Iluminismo e política ${ }^{24}$. No âmbito do reformismo ilustrado português, o Secretário de Estado, geralmente identificado como Pombal, seria "um agente do espírito científico iluminista ${ }^{25}$ " e, com ele, a monarquia preten-

Sociais, Instituto de Ciências Sociais da Universidade de Lisboa, 2005.

21 - Cf. AAVV. Como Interpretar Pombal? No bicentenário da sua morte. Lisboa-Porto: Edições Brotéria-Livraria A. I., 1983; Revista de História das Ideias. Coimbra: vol. 4: O Marquês de Pombal e o seu tempo. Número Especial no $2^{\circ}$ Centenário da sua morte, 1982-1983, 2 tomos; SANTOS, Maria Helena Carvalho dos (coord.). Pombal revisitado. Comunicações ao Colóquio Internacional organizado pela Comissão das Comemorações do $2^{\circ}$ Centenário da Morte do Marquês de Pombal. Lisboa: Editorial Estampa, 1984, 2 volumes.

22 - No campo da história social, vejam-se os importantes estudos de PEDREIRA, Jorge Miguel, Os homens de negócio da praça de Lisboa de Pombal ao vintismo (1755-1822). Tese de doutoramento - Faculdade de Ciências Sociais e Humanas da Universidade Nova de Lisboa. Lisboa: 1995, policopiado; MONTEIRO, Nuno Gonçalo. O Crepúsculo dos Grandes. A casa e o património da aristocracia em Portugal (1750-1832). Lisboa: Imprensa Nacional-Casa da Moeda, 1998 e, do mesmo autor, Elites e poder: entre o Antigo Regime e o Liberalismo. Lisboa: Imprensa de Ciências Sociais, 2003.

23 - Para uma interpretação recente do reinado de D. José, ver MONTEIRO, Nuno Gonçalo. D. José. Na sombra de Pombal. Lisboa: Círculo de Leitores, 2006; 2. edição, revista e ampliada, Lisboa: Temas e Debates, 2008. Para uma exposição das dinâmicas do império luso-brasileiro no contexto da história atlântica e prolongando a narrativa até meados do século XIX, ver PAQUETTE, Gabriel B.. Imperial Portugal in the age of Atlantic revolutions: the Luso-Brazilian world, c. 1770-1850. Cambridge: Cambridge University Press, 2013.

24 - Sobre esta perspectiva, ver, para Portugal, a síntese de CALAFATE, Pedro. Filosofia política. In: CALAFATE, Pedro (dir.). História do Pensamento Filosófico Português, vol. III: As Luzes. Lisboa: Caminho, 2001, p. 45-62.

25 - Cf. GAUER, Ruth M. Chittó. A influência das reformas pombalinas na moderni- 
deria concretizar o projecto de formação de um novo oficialato e de uma nova arquitectura institucional ao serviço do centro político. No quadro desta grelha de leitura, a reforma da Universidade de Coimbra, em 1772, constitui um momento-chave e um marco da introdução da "modernidade" em Portugal ${ }^{26}$. Ora, uma tal linha interpretativa, assente numa representação holista e "optimista" do movimento ou programa filosófico e cultural do Iluminismo contrasta com o estilhaçar historiográfico do Iluminismo, pois, salvo algumas posições dissonantes ou mais reservadas, a maioria dos textos vindos à lume no universo lusófono, mas não só, tende a apresentar-nos uma representação idealista e teleológica do Iluminismo e das suas manifestações em Portugal, vendo em todas as iniciativas ou reformas do período um cunho ilustrado e identificando um "sentido" no percurso político, social e económico da monarquia portuguesa ao longo de Setecentos, que se caracterizaria pelo "progresso" e por uma gradual "racionalização" da política e da administração, nomeadamente na organização do espaço e em matéria fiscal.

Apesar de ser possível detectar para o período do reinado de D. José I as afirmações de um novo ideário - na sequência, de resto, de um processo iniciado efectivamente na primeira metade de Setecentos e no âmbito do qual pontificaram grandes nomes da cultura portuguesa ${ }^{27}-$, justifica-se uma certa prudência na aplicação uniforme de uma grelha de leitura iluminista às décadas do reinado josefino ${ }^{28}$, um cuidado que, aliás, outros historiadores fizeram questão de recomendar antes de nós ${ }^{29}$. Devemos

dade brasileira. In: AAVV. Congresso O Marquês de Pombal e a sua época/Colóquio O século XVIII e o Marquês de Pombal. Actas. Pombal-Oeiras: Câmara Municipal de Pombal-Câmara Municipal de Oeiras, 2001, p. 47-61, maxime p. 48 para a citação. 26 - Sobre esta questão, ver, a título de exemplo, GAUER, Ruth Maria Chittó. A modernidade portuguesa e a reforma pombalina de 1772. Porto Alegre: Edipucrs, 1996.

27 - Em relação à cultura portuguesa de Setecentos, com particular ênfase no pensamento iluminista, ver a síntese de ARAÚJO, Ana Cristina. A Cultura das Luzes em Portugal. Temas e problemas. Lisboa: Livros Horizonte, 2003.

28 - Cf. DIAS, José Sebastião da Silva. Pombalismo e Teoria Política. Separata de Cultura - História e Filosofia. Lisboa: Centro de História da Cultura da Universidade Nova de Lisboa, 1982, p. 1: "Teoricamente, o absolutismo esclarecido não foi igual a si mesmo do princípio ao fim do pombalismo. E por outro lado, não nasceu feito. Fez--se aos poucos, de acordo com o apelo das lutas concretas em que sucessivamente se envolveu." 29 - Cf., entre outros, FALCON, Francisco José Calazans. As práticas do reformismo 
atender à cronologia; ao peso dos modelos, nomeadamente em matéria de economia política num contexto de competição imperial ${ }^{30}$, e das convenções herdadas; às tensões e diferenças que existiram no seio do movimento das Luzes, mormente "a preponderância do alinhamento católico das Luzes em Portugal ${ }^{31}$ ", que introduz um contraste com algumas das correntes do pensamento iluminista europeu ${ }^{32}$; à coexistência do "antigo" e do "moderno"; e à oposição corporativa a toda a mudança ${ }^{33}$. Em suma, importa contemplar as continuidades e as resistências, não ignorando a complexidade e a "contrapolaridade inquestionável ${ }^{34}$ " do Iluminismo, no-

ilustrado pombalino no campo jurídico. Revista de História das Ideias. Coimbra: vol. 18: História - Memória - Nação, p. 511-527, 1996, maxime p. 512-513.

30 - Cf. HONT, Istvan. Jealousy of Trade: International Competition and the NationState in Historical Perspective. Cambridge, MA.: Harvard University Press, 2005. Sobre a presença de modelos estrangeiros, nomeadamente ingleses, na definição das políticas de Sebastião José de Carvalho e Melo, ver PAQUETTE, Gabriel. Political economy, local knowledge and the reform of the Portuguese empire in the Enlightenment. In: ASTIGARRAGA, Jesús e USOZ, Javier (eds.). L'économie politique et la sphère publique dans le débat des Lumières. Madrid: Casa de Velázquez, 2013, p. 245-257, maxime p. 249-251. 31 - Cf. DIAS, José Sebastião da Silva. Pombalismo e Teoria Política, p. 17. Sobre esta questão, ver também SANTOS, Cândido dos. Matrizes do Iluminismo Católico da época Pombalina. In: AAVV. Estudos em Homenagem a Luís António de Oliveira Ramos. Porto: Faculdade de Letras da Universidade do Porto, 2004, p. 949-956, vol. 3.

32 - Cf. DIAS, José Sebastião da Silva. Pombalismo e projecto político. Cultura - História e Filosofia. 1984, p. 135-259, vol. III. Sobre esta questão, vejam-se também os dois estudos de DOMINGUES, Beatriz Helena. Algumas considerações sobre a relação entre Modernidade, Barroco e Iluminismo no mundo ibérico, 2001, e The Role of the Jesuits in the Iberian Catholic Enlightenment. 2003-2004. Disponível em: http://www.la.utexas. edu/research/paisano/paisano_three/BHDtext.html; http://www.georgetown.edu/centers/ woodstock/publications/Jesuits_in_Iberian_Enlightenment.htm\#_ftn1.

33 - A obra de Kenneth Maxwell constituirá, porventura, uma bōa síntese destas tensões e dos problemas de interpretação que a personagem de Sebastião José de Carvalho e Melo suscita. Ao definir Pombal como um "paradoxo do Iluminismo", o autor está, afinal, a afirmar a sua dificuldade em definir como ilustrado um governante com um ideário e práticas dissonantes em relação ao que comummente se entende por Iluminismo. Cf. MAXWELL, Kenneth. Pombal, Paradox of the Enlightenment. Cambridge: Cambridge University Press, 1995. Para uma crítica desta obra, considerando a necessidade de bem definir o que se entende por Iluminismo, ver MONTEIRO, Nuno Gonçalo. Maxwell, Kenneth. Pombal, Paradox of the Enlightenment. e-journal of Portuguese History. Vol. 11, n. ${ }^{\mathrm{o}}$ 1, Summer p. 110-119, 2013. Disponível em: //www.brown.edu/Departments/Portuguese_Brazilian_Studies/ejph/html/issue $21 / \mathrm{html} / \mathrm{v} 11 \mathrm{n} 1 \mathrm{a} 07 . \mathrm{html}$.

34 - A expressão é de PEREIRA, José Esteves. A Ilustração em Portugal. In: PEREIRA, José Esteves. Percursos de História das Ideias. Lisboa: Imprensa Nacional-Casa da Moeda, 2004, p. 91-103, maxime p. 91 para a citação. Esta "contrapolaridade", aliás, não é 
meadamente no espaço português e ibérico, sob risco de empobrecimento da história cultural e intelectual de Setecentos. A relativização da importância do período dito "pombalino" enquanto momento de afirmação das Luzes em Portugal sublinha "as limitações de abertura da modernidade do pombalismo 35 " e a desconfiança do poder face ao fermento de ideias e a alguns dos princípios defendidos por certas correntes iluministas.

Não iremos retomar aqui o debate em torno do pombalismo, dos respectivos fundamentos teóricos e da sua eventual "modernidade". Lembramos tão somente que já tivemos a oportunidade de defender e aplicar uma proposta teórica e metodológica ${ }^{36}$ que sustenta que é essencialmente nos documentos produzidos pela administração e na correspondência trocada entre o centro e as periferias que podemos apreender a cultura política do Antigo Regime ${ }^{37}$ e encontrar "des éléments déterminants du mode de penser politique de ceux qui agissaient ${ }^{38}$ ". Ou seja, é na

específica do caso nacional. Para o caso inglês, ver a excelente exposição de POCOCK, John G. A.. Clero y comercio: la Ilustración conservadora en Inglaterra. In: POCOCK, John G. A.. Historia e Ilustración. Doce estudios. Madrid: Marcial Pons Historia, 2002, p. 173-210. Este texto data originalmente de 1985.

35 - Cf. PEREIRA, José Esteves. Poder e saber. Alcance e limitações do projecto pombalino. In: PEREIRA, José Esteves. Percursos .... p. 133-140, maxime p. 135 para a citação. $\mathrm{O}$ autor segue aqui a interpretação de José Maurício de Carvalho. Ver ainda, no mesmo volume, "A Ilustração em Portugal", p. 91-103, e "Teorização absolutista e centralização", p. 107-123. De igual modo, consulte-se CHACON, Vamireh. O Humanismo Ibérico. A escolástica progressista e a questão da modernidade. Lisboa: Imprensa Nacional-Casa da Moeda, 1998, p. 31 e 57-58.

36 - Cf. RODRIGUES, José Damião. "para o socego e tranquilidade publica das Ilhas": .... p. 157-183; RODRIGUES, José Damião. Percursos de um magistrado nos Açores: a etapa açoriana de José Acúrsio das Neves. In: O Liberalismo nos Açores: do Vintismo à Regeneração. O Tempo de Teotónio de Ornelas Bruges (1807-1870). Angra do Heroísmo: Instituto Açoriano de Cultura, 2008, p. 147-160.

37 - Para uma avaliação crítica do conceito de "cultura política" e do seu uso por historiadores e cientistas políticos, ver, entre outros, FORMISANO, Ronald P.. The Concept of Political Culture. Journal of Interdisciplinary History. Vol. XXXI, n. ${ }^{\circ}$ 3, p. 393-426, Winter 2001. Para a sua aplicação aos casos de Portugal, do Brasil e do Atlântico português, ver SOIHET, Rachel; BICALHO, Maria Fernanda Baptista e GOUVÊA, Maria de Fátima Silva (org.). Culturas políticas: ensaios de história cultural, história política e ensino de história. Rio de Janeiro: Mauad, 2005.

38 - Cf. PASQUINO, Pasquale. Police spirituelle et police terrienne. D. Reinkingk et V. L. von Seckendorff. In: LAZZERI, Christian e REYNIÉ, Dominique (ed.). La raison d'Etat: politique et rationalité. Paris: PUF, 1992, p. 83-115, maxime p. 85 para a citação. 
comunicação política que existia entre a monarquia e os diferentes pólos de poder, mesmo aqueles que eram uma extensão periférica da coroa, que podemos detectar o modo como o governo representava os corpos políticos e sociais e perceber quais eram os objectivos do centro político relativamente aos territórios e às populações sob a sua jurisdição ${ }^{39}$. No caso concreto do período aqui considerado, tal metodologia adquire particular relevância quando consideramos que o reinado de D. José I, em termos históricos e historiográficos, se caracteriza por ser um período de polaridades opostas e no qual a "modernidade" política se parece consubstanciar, tal como no tempo do conde-duque Olivares, na prática de um governo "activo", que procurava romper com os equilíbrios tradicionais.

A emergência de um modelo de administração activa, que pretendia reorganizar o todo social, relaciona-se com o desenvolvimento, durante a primeira metade do século XVIII, de uma "ciência de polícia", de matriz cameralista, que propunha um modelo de administração activa ${ }^{40}$. Será então aqui que podemos encontrar os eventuais elementos de "modernidade" ou "novidade" do governo de Sebastião José de Carvalho e Melo, num reformismo activo de inspiração cameralista ${ }^{41}$ que aspirava

39 - A este respeito, veja-se o texto da carta de Sebastião José de Carvalho e Melo a Joaquim de Melo e Póvoas, governador do Maranhão, onde o então conde de Oeiras expõe "um breve methodo de governar", com recurso a uma linguagem tradicional. Cf. ALBUQUERQUE, Martim de. Para a história das Ideias Políticas em Portugal. Uma carta do Marquês de Pombal ao governador do Maranhão em 1761. In: ALBUQUERQUE, Martim de. Estudos de Cultura Portuguesa. Lisboa: Imprensa Nacional-Casa da Moeda, 2002, p. 331-342, vol. III.

40 - Cf. SUBTIL, José. Os poderes do centro. Governo e administração. In: HESPANHA, António Manuel (coord.). O Antigo Regime (1620-1807). Quarto Volume da História de Portugal, dir. José Mattoso. Lisboa: Círculo de Leitores, 1993, p. 157-193, maxime p. 159-163 para o "Estado de polícia". Sobre o conceito de "polícia", ver SCHIERA, Pierangelo. A "polícia" como síntese de ordem e de bem-estar no moderno Estado centralizado. In: HESPANHA, António Manuel (org.). Poderes e Instituições na Europa .... p. 307-319. É de notar que o conceito de "polícia" também era conhecido em Portugal e foi registado pelo padre Rafael Bluteau no seu Vocabulario Portuguez, \& Latino ainda no primeiro quartel de Setecentos. Cf. BLUTEAU, Rafael. Vocabulario Portuguez, \& Latino, [...]. Lisboa: na Oficina de Pascoal da Silva, 1720, p. 575.

41 - José Luís Cardoso considerou que, entre as inspirações doutrinais e políticas que alimentaram um ambiente propício à mudança no contexto do reformismo iluminado que caracterizou a governação de Sebastião José de Carvalho e Melo, devemos incluir o cameralismo austríaco-alemão. Cf. CARDOSO, José Luís. Direito natural e despotismo legal: a 
a romper com um modelo administrativo "passivo" e o equilíbrio de poderes tradicional, procurando impor uma diferença enquanto estratégia política $^{42}$. Para tentar impor ao reino e ao império as reformas desejadas, o Secretário de Estado precisou recorrer a uma nova prática governati$\mathrm{va}^{43}$. É, então, a partir desta grelha que iremos observar e comentar as iniciativas de reforma operadas durante o reinado de D. José I, bem como os resultados alcançados, tomando como objecto de análise os territórios portugueses do Atlântico, situando-os no seu contexto internacional e atlântico e contribuindo assim para restituir uma mais correcta compreensão do regalismo josefino e das condições efectivas do exercício do poder neste período ${ }^{44}$.

2. Comecemos por sublinhar, como destacou o historiador Jorge Borges de Macedo, que as políticas seguidas pelo Secretário de Estado Sebastião José de Carvalho e Melo não representaram uma ruptura total com as grandes linhas definidas no reinado de D. João V. Com efeito, durante o reinado de D. José I foram continuados "alguns dos princípios essenciais que orientavam o governo de D. João V: aliança inglesa e neutralidade na Europa, a independência e unidade na direcção do Estado ${ }^{45}$ ".

ordem e o discurso fisiocrático em Portugal. In: CARDOSO, José Luís. Pensar a Economia em Portugal - Digressões Históricas. Lisboa: Difel, 1997, p. 119-135, maxime p. 127. 42 - Cf. WILSON, Kathleen. Introduction: histories, empires, modernities. In: WILSON, Kathleen (ed.). A New Imperial History: Culture, Identity, and Modernity in Britain and the Empire, 1660-1840. Cambridge: Cambridge University Press, 2004, p. 1-26, maxime p. 8. É ainda esta historiadora que, a propósito da "diferença", afirma que esta era "a political strategy rather than a verifiable descriptive category, a highly mobile signifier for power relations" (idem, p. 4).

43 - Para a nossa análise, seguimos a grelha analítica concebida por Michel Foucault. Em particular, sublinhamos a distinção que o autor estabeleceu entre a crítica do "reformismo como prática política" e a de uma "prática política no pressuposto de que pode dar origem a uma reforma" e os três conceitos de "formas de racionalidade" necessários a uma interpretação das relações de poder - estratégias, tecnologias e programas de poder -, alertando ainda para a diferença entre discursos, práticas e efeitos sociais. Cf. RODRIGUES, José Damião. "para o socego e tranquilidade publica das Ilhas ”: .... p. 157-183, maxime p. 149-152 e a bibliografia aí indicada.

44 - Sobre estas questões, ver CHAUNU, David e DUC, Séverin (eds.). La domination comme expérience européenne et américaine à l'époque moderne. Bruxelles-Bern-Berlin-New York-Oxford-Wien: Peter Lang, 2019.

45 - Cf. MACEDO, Jorge Borges de. O Marquês de Pombal (1699-1782). Lisboa: Biblioteca Nacional, 1982, p. 18. 
Por outro lado, o mesmo historiador notara, em síntese agora clássica, que não podemos pretender que o período de vinte e sete anos de permanência de Sebastião José de Carvalho e Melo no governo tenha tido sempre as mesmas características ou sequer que os modelos políticos subjacentes à acção governativa estivessem configurados desde a chamada do futuro marquês de Pombal à Secretaria dos Negócios Estrangeiros e da Guerra ${ }^{46}$. José Sebastião da Silva Dias também sublinhou este aspecto, ou seja, o facto de que a governação durante o reinado josefino não foi igual do princípio ao fim, devendo ser perspectivada como um conjunto de respostas políticas a diferentes desafios ${ }^{47}$. Assim, no arco cronológico que se estende de 1750 a 1777, são identificáveis diversas conjunturas, que exigiram do poder respostas adequadas à situação interna e externa.

No primeiro decénio do reinado de D. José I, importa lembrar que algumas das decisões tomadas não devem ser imediatamente atribuídas ao pensamento ou à influência do novo Secretário de Estado Sebastião José de Carvalho e Melo, resultando antes de dinâmicas e solicitações que vinham do reinado anterior. Podemos referir a criação do Tribunal da Relação do Rio de Janeiro, em 1751; a autonomização do governo de Moçambique do Estado da Índia, em 1752; ou a mudança da capital das ilhas do Golfo da Guiné de São Tomé para a vila, de imediato elevada à cidade, de Santo António, no Príncipe, em 1753, acompanhando a incorporação da ilha nos bens da coroa. Na década seguinte, ainda no decurso das sequelas dos tratados negociados entre as monarquias ibéricas e ao cair do pano da Guerra dos Sete Anos, em 1763, o Rio de Janeiro tornou-se a nova capital do Estado do Brasil, culminando o movimento que deslocara para a região centro-sul o eixo político e económico da América portuguesa. A centralidade do Rio de Janeiro, agora formalmente afirmada, era também fruto das novas circunstâncias geopolíticas no Atlântico

46 - Cf. MACEDO, Jorge Borges de. Pombal, Marquês de (1699-1782). In: SERRÃO, Joel (dir.). Dicionário de História de Portugal. S. ed. Porto: Livraria Figueirinhas, 1981, p. 113-121, vol. V. Este texto data, na sua origem, do final dos anos de 1960.

47 - Cf. DIAS, José Sebastião da Silva. Pombalismo e Teoria Política. Separata de Cultura-História e Filosofia. p. 1. 
$\mathrm{Sul}^{48}$. Por outro lado, reformas que tiveram a mão do então já conde de Oeiras não se configuraram como uma manifestação do "despotismo esclarecido", antes foram a resposta a uma conjuntura de crise fiscal, como sucedeu com a criação da capitania-geral dos Açores, instituída em 1766. Por fim, importa ainda situar as reformas ditas "pombalinas" no quadro europeu. $\mathrm{O}$ ímpeto reformista não foi um exclusivo português, bastando para tal olhar para os territórios americanos da monarquia bourbónica, onde é possível identificar uma "avalanche reformista" de 1777 a 1787 , com diferenças regionais assinaláveis e resultados limitados e desapontadores. Estes surtos de reformas, de mudanças institucionais, devem ser encarados como respostas adaptativas a alterações registadas nas dinâmicas imperiais e no equilíbrio das relações internacionais de $\operatorname{poder}^{49}$. E a sua coincidência cronológica com os tempos fortes do Iluminismo não significa que na base das reformas tenham estado necessariamente preceitos ilustrados, ou seja, a aplicação de princípios racionalistas em prol de um reformismo administrativo.

Observando agora alguns dos territórios portugueses do Atlântico, vejamos, de forma breve, que reformas a coroa procurou implementar, quais as conjunturas e os contextos e que resultados foram atingidos.

Comecemos pelos Açores. De um modo geral, na constelação das "reformas pombalinas", as ilhas ocupam uma região periférica relativamente ao núcleo daquelas, composto pelos espaços e temas "fortes" dos discursos historiográficos. Tal facto poderá ser explicado por uma questão de escala, considerando-se que, pela sua dimensão, os exemplos recolhidos nos Açores têm sobretudo interesse regional. Deste modo, o

48 - Sobre esta conjuntura, ver uma síntese em RODRIGUES, José Damião. Um tempo de ruptura? (1750-1778). p. 264-276.

49 - Cf. DELGADO RIBAS, Josep M.. Dinámicas imperiales (1650-1796). España, América y Europa en el cambio institucional del sistema colonial español. Barcelona: Edicions Bellaterra, 2007, p. 21-22, 32 e 36-37. Para uma comparação e avaliação das reformas ibéricas nas Américas, ver MONTEIRO, Nuno Gonçalo. Reformas pombalinas e reformas bourbónicas nas Américas: esboço de uma análise comparada. In: GARRIDO, Álvaro, COSTA, Leonor Freire e DUARTE, Luís Miguel (orgs.). Estudos em homenagem a Joaquim Romero Magalhães. Economia, instituições e império. Coimbra: Almedina, 2012, p. 373-390. 
impacto das reformas e da acção governativa do conde de Oeiras nos arquipélagos portugueses do Atlântico e, em particular, nos Açores tem sido descurado por historiadores nacionais e estrangeiros, com a inevitável excepção da historiografia produzida em meios insulares ou com estes relacionados ${ }^{50}$, não obstante configurarem um bom exemplo - um case study - das ambições, possibilidades e limites que se colocavam aos diversos projectos reformistas das monarquias europeias e ao desígnio de instaurar uma nova ordem social.

Em meados do século XVIII, três séculos após o início do povoamento das ilhas dos Açores, a partir do seu perímetro oriental, estaríamos, segundo algumas interpretações, perante uma "deterioração do sistema político-administrativo insular" ${ }^{51}$ ". A coroa não dispunha de meios efectivos para levar a cabo um qualquer projecto centralizador e, no caso dos Açores, a distância do reino, a fragmentação geográfica e a persistência de estruturas senhoriais que datavam do começo da ocupação humana do arquipélago ampliavam as dificuldades da monarquia em impor um maior controlo aos poderes periféricos ${ }^{52}$. Deste modo, as reformas que, na década de 1760, o conde de Oeiras concebeu para os Açores não visavam responder ao "abandono" e "decadência" das ilhas, devendo antes ser enquadradas nas respectivas conjunturas nacional e internacional, por um lado, e no contexto da implementação de um novo paradigma administrativo, que melhor correspondesse às urgências da coroa portuguesa,

50 - Para uma exposição do projecto de reformas nos Açores, seus objectivos, limites e resultados, ver MENESES, Avelino de Freitas de. Os Açores nas encruzilhadas de Setecentos (1740-1770), vol. I: Poderes e instituições. Ponta Delgada: Universidade dos Açores, 1993 e vol. II: Economia. Ponta Delgada: Universidade dos Açores, 1995; LEITE, José Guilherme Reis. Administração, sociedade e economia dos Açores, 1766-1793. Arquivo Açoriano. Enciclopédia das Ilhas dos Açores. Vol. 16 $6^{\circ}$, Parte 2a , Fascículos 14 a 23, p. 267-368, 1971; vol. 16 ${ }^{\circ}$, Parte $3^{\text {a }}$ (e última), Fascículos 24 a 35, p. 369-475, 1972; RODRIGUES, José Damião. "para o socego e tranquilidade publica das Ilhas": ....

51 - Cf. MENESES, Avelino de Freitas de. Os Açores nas encruzilhadas .... p. 52, vol. I. 52 - Sobre esta questão, ver RODRIGUES, José Damião. São Miguel no século XVIII: casa, elites e poder. Ponta Delgada: Instituto Cultural de Ponta Delgada, 2003 [2004], p. 94-98, vol. I; RODRIGUES, José Damião. Um arquipélago de geometria variável: representações dos Açores no período moderno. Revista de História Regional. Ponta Grossa: vol. 13, n. ${ }^{\circ}$ 1, p. 7-22, Verão 2008 [reeditado in RODRIGUES, José Damião. Histórias Atlânticas: os Açores na primeira modernidade. Ponta Delgada: CHAM, 2012, p. 33-43]. 
por outro. De resto, Portugal não estava só no que respeita aos impulsos de reformar ou reorganizar as instituições e o governo da monarquia, na medida em que os oponentes da Guerra dos Sete Anos estavam esgota$\operatorname{dos}^{53}$ e as consequências desastrosas do conflito para algumas das partes pensamos sobretudo no caso de França - estiveram na origem de projectos que buscavam encontrar uma saída para a crise. Em suma, a crise na economia e nas finanças públicas reclamou a atenção do poder, sobretudo nos anos de 1764 a 1770, período durante o qual a energia governativa se dirigiu essencialmente para o "reforço dos privilégios mercantis e da cobrança de impostos ${ }^{54}$ ". Assim, e apesar das interrogações que se colocam sobre a existência de "um coerente modelo de actuação no plano económico ${ }^{55 ",}$ podemos afirmar que as medidas administrativas adoptadas pela coroa portuguesa na década de 1760 obedeceram também a preocupações "fiscalistas", almejando, no limite, "établir une nouvelle fonctionnalité économique impériale ${ }^{56 "}$.

Nos Açores, as reformas do conde de Oeiras introduziram diversas alterações no mapa do governo político e jurídico e, concomitantemente, na rede de poderes insulana. Os parâmetros de actuação do primeiro executor das reformas no terreno, D. Antão de Almada, segundogénito da casa dos senhores de Pombalinho e mestres-sala da Casa Real, homem da confiança do conde de Oeiras e de seu irmão, Francisco Xavier de

53 - Cf. BOIS, Jean-Pierre. De la paix des rois à l'ordre des empereurs (1714-1815). Paris: Éditions du Seuil, 2003, p. 186-202 para uma síntese da Guerra dos Sete Anos e dos tratados de 1763; SCHUMANN, Matt e SCHWEIZER, Karl. The Seven Years War: A Transatlantic History. New York: Routledge, 2008; BAUGH, Daniel. The Global Seven Years' War. Harlow: Longman, 2011.

54 - Cf. MACEDO, Jorge Borges de. Pombal, Marquês de (1699-1782). p. 113-121, vol. $\mathrm{V}$, maxime p. 117. Sobre a crise económica deste período, ver MACEDO, Jorge Borges de. A situação económica no tempo de Pombal - alguns aspectos. $3^{\mathrm{a}}$ ed.. Lisboa: Gradiva, 1989 [edição original: 1951].

55 - Cf. CARDOSO, José Luís CARDOSO. Política económica. In: LAINS, Pedro e SILVA, Álvaro Ferreira da (org.). História económica de Portugal, vol. I: O Século XVIII. Lisboa: Imprensa de Ciências Sociais, 2005, p. 345-367, maxime p. 355-362 para a política económica no período pombalino (citação da p. 355).

56 - Cf. GIRALDO, Manuel Lucena. Le réformisme de frontière. Histoire et sociétés de l'Amérique latine. N. ${ }^{\text {7, }}$ p. 209-220, premier semestre 1998, maxime p. 210 para a citação. 
Mendonça, foram fixados em dois documentos: um, público, o alvará de lei e regimento, de 2 de Agosto de 1766; e outro, secreto, a "Instrução particular [...] para o seu governo secretissimo [...]" ou "Instrucção Secretissima", com a mesma data ${ }^{57}$. É na "Instrucção Secretissima" que se manifesta a cultura política dos agentes do poder e se revelam as concepções e os objectivos da monarquia para o arquipélago, justificados pela utilidade das ilhas ${ }^{58}$. De um modo geral, estamos perante a confluência de uma velha ${ }^{59}$ e uma nova "razão de Estado", que se pensa "ciência da polícia" ou "ciência da administração ${ }^{60 "}$.

O novo governador e capitão-general era instruído sobre o local de residência (Angra); a urgência de proceder a uma inventariação rigorosa

57 - Cf. O Códice 529-Açores do Arquivo Histórico Ultramarino. A Capitania-Geral dos Açores durante o consulado pombalino. Introdução e fixação do texto por José Guilherme Reis Leite, Angra do Heroísmo-Ponta Delgada, Secretaria Regional de Educação e Cultura/Direcção Regional dos Assuntos Culturais-Universidade dos Açores/Centro de Estudos Gaspar Frutuoso, 1988, p. 28-35 e 35-58, respectivamente. No segundo documento, a "razão de Estado", presente ao longo das instruções confiadas ao capitão-general, revela-se logo no início, com a confissão de que a sua natureza exige "a circunspecção de mais delicado segredo" (idem, p. 36).

58 - O texto da "Instrucção Secretissima, [...]" refere "as uteis Ilhas Terceiras vulgarmente chamadas dos Açores”. Cf. O Códice 529-Açores ..., cit., p. 36 (itálico nosso). O princípio da utilidade pública pode ser encontrado em António Ribeiro Sanches, um dos mentores das políticas pombalinas. Cf. SERRÃO, José Vicente. O pensamento agrário setecentista (pré-«fisiocrático»): diagnósticos e soluções propostas. In: CARDOSO, José Luís (org.). Contribuições para a história do pensamento económico em Portugal. Lisboa: Publicações Dom Quixote, 1988, p. 23-50, maxime p. 29-30 e 37-38. Para uma análise deste documento e de outros conexos, ver RODRIGUES, José Damião. "para o socego e tranquilidade publica das Ilhas": .... p. 157-183, maxime p. 160-166.

59 - A "razão de Estado", tal como foi formulada por Giovanni Botero, não ignorava a importância do inventário dos recursos do Estado: "L'innovation de Botero est de conférer à la raison d'État un véritable domaine de réalité. [...] La stratégie est statistique. [...] elle trouve sa raison dans l'analyse des ressources et leur exploitation équilibrée." Cf. SFEZ, Gérald. Les doctrines de la raison d'État. Paris: Armand Colin, 2000, p. 60-61 (em itálico no original).

60 - Cf. REYNIÉ, Dominique. Le regard souverain. Statistique sociale et raison d'Etat du XVI ${ }^{\mathrm{e}}$ au XVIII ${ }^{\mathrm{e}}$ siècle. In: LAZZERI, Christian e REYNIÉ, Dominique (ed.). La raison d'Etat: .... p. 43-82, maxime p. 62-63. Veit Ludwig von Seckendorff recusava a noção de "razão de Estado", embora o seu pensamento se inscrevesse na tradição de um Giovanni Botero. A "razão de Estado" e a "polícia", apesar das diferenças, tinham em comum a preocupação com o inventário dos recursos do Estado, que a gute Polizei levará mais longe. SFEZ, Gérald. Les doctrines de la raison d'État. p. 163. 
do estado dos corpos militares ${ }^{61}$, da Fazenda Real (número de oficiais e suas qualidades, repartições, receitas e despesas das folhas eclesiástica, civil e militar) e da justiça régia (informação sobre todos os bacharéis que serviam nas ilhas); e a respectiva jurisdição e o relacionamento com outras instâncias de poder, nomeadamente a boa correspondência com as pessoas eclesiásticas, a fiscalização do comportamento dos oficiais régios e o controlo da actuação das câmaras no tocante à apropriação indevida de terrenos. Com estes diplomas, reorganizava-se a corregedoria dos Açores, de novo dividida em duas, tal como acontecera entre $1534 \mathrm{e}$ 1544; nomeavam-se juízes de fora para a cidade de Angra e as vilas mais importantes de cada ilha - em São Miguel, a cidade de Ponta Delgada tinha um juiz de fora desde 1554 -; e alterava-se o sistema eleitoral dos principais concelhos insulanos com a introdução do sistema das pautas régias enviadas pelo Desembargo do Paço em Ponta Delgada e nas vilas mais importantes. Deste vasto plano, chamemos ainda a atenção para o projecto de reorganização militar, que coincidia com a esperada instalação na Terceira do Regimento Insulano ${ }^{62}$, e para o acento colocado na aplicação das "minhas Leys de Policia" em matéria de justiçaç

61 - O capitão-general devia elaborar um mapa militar para cada uma das ilhas, com o registo do número de homens e fortalezas, informação que devia ser coligida anualmente, e, em paralelo, cuidaria de informar o centro político das qualidades dos oficiais e soldados das companhias de auxiliares e das ordenanças com vista à organização de terços. Cf. O Códice 529-Açores .... p. 28-29.

62 - Cf. O Códice 529-Açores .... p. 134-143, "Alvará de 2 de Agosto de 1766. Extinguem-se as Ordenanças de pé de Castelo, e se mandam criar tropas regulares para a guarnição das Ilhas dos Açores". Anexo ao alvará, encontra--se o plano do regimento de infantaria e artilharia que guarneceria os castelos das ilhas açorianas.

63 - Cf. $O$ Códice 529-Açores .... p. 32-33. O monarca refere-se às leis de 25 de Junho e 19 de Agosto de 1760, 20 de Outubro de 1763 e 24 de Outubro de 1764. A primeira diz respeito aos emolumentos dos corregedores e escrivães criminais, com alusão clara à questão da "segurança publica" e a uma lei anterior, promulgada "para a Policia, e conservaçaõ da tranquilidade publica da minha Corte"; a segunda, datada de 13 de Agosto e publicada a 19 desse mês, é a conhecida lei que reforma os passaportes. Cf. Collecçaõ das Leys, Decretos, e Alvarás, que comprehende o feliz reinado Del Rey Fidelissimo D. Jozé o I. Nosso Senhor Desde o anno de 1750 até o de 1760, e a Pragmatica do Senhor Rey D. Joaõ o V. do anno de 1749., Tomo I. Lisboa: na Oficina de António Rodrigues Galhardo, 1771, sem indicação de p. ou fl. 
O conde de Oeiras esperava afirmar a superioridade do centro político sobre as instâncias periféricas de dominação e, conforme escreveu então o provedor da Fazenda Real nos Açores, Manuel de Matos Pinto de Carvalho, um dos principais informantes do Secretário de Estado nas ilhas, as medidas implementadas pretendiam ser "de uma grande consequencia para o socego e tranquilidade publica das Ilhas ${ }^{64 \%}$, expressão que se enquadra bem nos objectivos da teoria administrativa da Policey, a "polícia ${ }^{65 " . ~ D e ~ f o r m a ~ i n e q u i ́ v o c a, ~ e m ~ i n s t r u c ̧ a ̃ o ~ d i r i g i d a ~ a o ~ r e c e ́ m-n o-~}$ meado corregedor da comarca das ilhas de São Miguel e Santa Maria, o conde de Oeiras informava, a propósito do perdão geral concedido aos moradores das ilhas: "Uzando Sua Magestade da sua benignissima clemencia, mandou expedir hum Perdão Geral de todos os dilictos preteritos, que podião caber na indulgencia para principiar hum Mundo novo ${ }^{66 "}$. Principiar um mundo novo, ou seja, refundar a ordem política e social, seria a ambição do conde de Oeiras e do modelo de administração activa, de inspiração cameralista, que procurava impor aos territórios da monarquia. Na prática, este foi um desígnio falhado. Com efeito, ao equacionarmos os objectivos de reformas imaginadas no centro e o impacto efectivo das mesmas nas periferias, ultrapassando o quadro normativo, as afirmações ideológicas dos actores e as interpretações historiográficas que viram a imposição de uma política "moderna" face a estruturas "arcaicas" ou obsoletas", não podemos ignorar que continuamos a falar de sociedades tradicionais de Antigo Regime, nas quais imperava o respeito

64 - Cf. Arquivo dos Açores. Edição fac-similada da edição original. Ponta Delgada: Universidade dos Açores, vol. VI, 1981, pp. 21-40, maxime p. 27 para a citação.

65 - Manuel de Matos Pinto de Carvalho serviu cinco anos como provedor da Fazenda Real dos Açores e, com base na sua experiência, elaborou uma representação onde expôs "o mais que observei respectivo ao publico e policia particular de cada uma [das ilhas]" (idem, p. 26 para a citação). O bacharel Manuel de Matos Pinto de Carvalho foi nomeado provedor da Fazenda Real dos Açores por alvará de 25 de Janeiro de 1760 e, meses depois, a 8 de Maio, foi contemplado com uma carta de padrão de 12.000 réis de tença com o hábito da Ordem de Cristo, a vencer desde 11 de Abril desse ano, dia em que se lhe passara a provisão. No final do seu exercício, por diplomas de 6 de Fevereiro de 1765, o desembargador recebeu o alvará de cavaleiro da Ordem de Cristo, a carta de lançamento do hábito e o alvará de profissão. Cf. Arquivo Nacional da Torre do Tombo (ANTT), Chancelarias Antigas da Ordem de Cristo, Livro 220, fls. 362-362 v; Livro 270, fls. 85-85 v; e Livro 277, fls. 374-374 v.

66 - Cf. O Códice 529-Açores .... p. 154-157, maxime p. 154 para a citação. 
pelas "liberdades", isto é, os privilégios, e a defesa da autonomia dos corpos políticos e sociais. As reformas continuavam a ter de enfrentar a visão corporativa da sociedade, concepção que defendia a partilha do poder e a autonomia jurisdicional dos corpos sociais, entre outros "obstáculos fácticos a um qualquer projecto de centralização ${ }^{67}$ ". Nos Açores, ao longo da segunda metade do século XVIII e apesar da vasta jurisdição que lhes foi outorgada, os capitães-generais não conseguiram aplicar as medidas plasmadas nos diplomas de 2 de Agosto de 1766.

É verdade que a instalação de um novo pólo de poder na cidade de Angra, sede da capitania geral, perturbou o equilíbrio político e jurisdicional vigente, sobretudo à escala local. D. Antão de Almada, desde o dia em que desembarcou em Angra acompanhado pela sua família e comitiva, a 28 de Setembro de 1766, afirmou-se como um interlocutor-chave na comunicação política entre a corte e as ilhas e dentro do espaço arquipelágico $^{68}$. Mas os ofícios que o capitão-general enviou para a corte revelam a consciência que tinha das dificuldades que enfrentava e de como procurava apoiar-se em colaboradores de confiança para ultrapassar "os enredos e embrulhadas das Ilhas ${ }^{69}$ ". A recepção do modelo político-administrativo da capitania geral por parte das populações insulanas não correspondeu ao que era esperado pela coroa. De igual modo, o controlo das nobrezas concelhias ficou muito aquém do objectivo inicial. O sistema das pautas

67 - Cf. HESPANHA, António Manuel. Poder e Instituições no Antigo Regime. Guia de Estudo. Lisboa: Edições Cosmos, 1992, p. 22.

68 - Para Ponta Delgada, num universo de 927 documentos relativos a instituições produtoras e emissoras de correspondência nos séculos XVII e XVIII, após a cabeça da monarquia (monarca ou príncipe), com 522 registos, e o Desembargo do Paço, com 148 registos, figura a capitania geral, com 38 documentos. E se tomarmos como período de análise apenas os anos subsequentes à instituição da capitania geral, o protagonismo do governador torna-se mais visível: nos anos 1760-1797, o capitão-general foi responsável por 23 documentos recebidos e registados na câmara de Ponta Delgada, ultrapassando o monarca (rei ou rainha), com 21 registos. Cf. Biblioteca Pública e Arquivo Regional de Ponta Delgada (BPARPD), Arquivo da Câmara de Ponta Delgada (ACPD), 117, Livro $4 .^{\circ}$ do Registo (1760-1797), dados recolhidos no âmbito do projecto PTDC/HIS-HIS/098928/2008, A comunicação política na monarquia pluricontinental portuguesa (1580-1808): Reino, Atlântico e Brasil. Em relação a Angra, importa perceber em que medida a instalação da sede da capitania geral em Angra introduziu um elemento de desvio, por excesso, na comunicação política. Esta análise está ainda em curso.

69 - Cf. Arquivo dos Açores. 1981, p. 535, vol. V. 
régias não produziu os efeitos desejados e casos houve de oficiais camarários que se instalaram nos senados concelhios durante longos anos, sem que os representantes da coroa os incomodassem ${ }^{70}$. Por fim, além das dificuldades de comunicação que existiam entre as ilhas durante os meses de Inverno, impedindo que os juízes de fora das ilhas vizinhas se deslocassem à Terceira ${ }^{71}$, importa dizer que alguns juízes letrados constituíram um foco de instabilidade à escala local, fomentando parcialidades e perturbando a paz pública ${ }^{72}$.

Em síntese, entre as medidas que foram fixadas em diplomas e os resultados práticos das reformas, o hiato foi significativo. Recordemos a este propósito as palavras de José de Medeiros da Costa Albuquerque, governador de São Miguel e filho segundo da elite de Ponta Delgada, que, em 1797, escreveu uma representação denunciando o fracasso das reformas do conde de Oeiras no plano militar nas ilhas dos Açores. Segundo o governador, a orgânica concebida por Sebastião José de Carvalho e Melo resultara apenas em despesas para a Fazenda Real e as reformas tinham transformado a ilha Terceira, "capital das outras", em "um monstro enorme, com a cabeça de formiga e membros de gigante ${ }^{73}$ ". Não admira, pois,

70 - Cf. DRUMMOND, Francisco Ferreira. Anais da Ilha Terceira. Reimpressão fac-similada da edição de 1850-1864. Angra do Heroísmo: Secretaria Regional de Educação e Cultura, 1981, p. 49-50, 69-70, 81 e 95-96, vol. III; MENESES, Avelino de Freitas de. Os Açores nas encruzilhadas .... p. 112 e 216-221, vol. I, Quadros N. 7 a 9; RODRIGUES, José Damião. São Miguel no século XVIII .... p. 358-418, vol. I; RODRIGUES, José Damião. Orgânica militar e estruturação social: companhias e oficiais de ordenança em São Jorge (séculos XVI-XVIII). In: O Faial e a periferia açoriana nos séculos XV a XX. Horta: Núcleo Cultural da Horta, 1998, p. 527-550, maxime p. 543-544 [reeditado in RODRIGUES, José Damião. Histórias Atlânticas: .... p. 129-153, maxime p. 145-146]. 71 - Cf. MENDES, António Maria de Ornellas Ourique. Compilação e anotações às cartas e ofícios remetidos pelo primeiro capitão-general, D. Antão de Almada, ao Conde de Oeiras, a Francisco Xavier de Mendonça Furtado e a Martinho de Melo e Castro e que se acham no Arquivo Histórico Ultramarino e no Arquivo Nacional da Torre do Tombo. Arquivo Açoriano. Enciclopédia das Ilhas dos Açores. Vol. 16 ${ }^{\circ}$, Parte 1a , fascículos 1 a 13, p. 19-41, 69-85, e 101-121, 1971, maxime p. 25-26.

72 - Cf. Arquivo dos Açores. 1981, p. 532-533, vol. V; 1981, p. 9-14, vol. VI. Para a Horta, veja-se RODRIGUES, José Damião. "Com exorbitância inaudita": elites locais e magistrados régios na Horta em finais de Setecentos. In: GARRIDO, Álvaro; COSTA, Leonor Freire e DUARTE, Luís Miguel (orgs.). Estudos em homenagem a Joaquim Romero Magalhães. .... p. 215-225.

73 - Cf. Arquivo dos Açores. 1983, p. 492-507, vol. XII, maxime p. 503 para a citação. 
que, face aos mitigados resultados, a coroa tenha decidido "refundar" a capitania geral no final da centúria, sob a égide de um novo programa reformista, agora encabeçado por D. Rodrigo de Sousa Coutinho (1755$1812)^{74}$.

$\mathrm{Na}$ região da Guiné do Cabo Verde, a crise que afectava as ilhas cabo-verdianas desde meados do século XVII e a presença da navegação europeia no litoral africano e em Cabo Verde constituíam factores de bloqueio ao crescimento económico. Em 1713, o Conselho Ultramarino apresentou uma proposta para que os moradores de Santiago se organizassem em companhias, entrando assim no comércio com a costa africana; anos depois, porém, o governador de Cabo Verde afirmaria que tal projecto era impraticável devido à falta de capital, responsável pelo abandono dos principais centros urbanos das ilhas e pela ruralização. A reorganização do mapa político e administrativo de Cabo Verde pela carta régia de 27 de Agosto de 1731 não travou este processo ${ }^{75}$. Perante este cenário negativo, algumas décadas mais tarde, houve quem pensasse que a actuação da Companhia Geral do Grão-Pará e Maranhão em Cabo Verde seria benéfica para as ilhas, permitindo à sociedade e à economia locais recuperarem do marasmo em que se encontravam.

A Companhia Geral do Grão-Pará e Maranhão foi fundada pelo alvará de 7 de Junho de 1755, vindo a ser extinta por decreto de 5 de Janeiro de

74 - Sobre D. Rodrigo de Sousa Coutinho, ver SILVA, Pedro Miguel Carvalho Alves da. O dispotismo luminozo: introdução ao pensamento de Dom Rodrigo de Sousa Coutinho. Dissertação (Mestrado em História Cultural e Política) - Faculdade de Ciências Sociais e Humanas da Universidade Nova de Lisboa. Lisboa, 1997, policopiado; e SILVA, Andrée Mansuy-Diniz. Portrait d'un homme d'État: D. Rodrigo de Souza Coutinho, Comte de Linhares 1755-1812, vol. I: Les années de formation 1755-1796. Lisboa-Paris: Centre Culturel Calouste Gulbenkian -Comissão Nacional para as Comemorações dos Descobrimentos Portugueses, 2002. Para a segunda vida da capitania geral, ver COSTA, Ricardo Manuel Madruga da. Os Açores em finais do regime de Capitania-Geral (1800-1820). Horta: Núcleo Cultural da Horta, 2005, 2 vols..

75 - Cf. SILVA, António Correia e. Dinâmicas de decomposição e recomposição dos espaços e sociedades. In: SANTOS, Maria Emília Madeira (coord.). História Geral de Cabo Verde, vol. III. Lisboa-Praia: IICT-IIPC, 2002, p. 32-66; BALENO, Ilídio. Reconversão do comércio externo em tempo de crise e o impacto da companhia do Grão-Pará e Maranhão. In: ibidem. p. 157-233. 
1778. Foi a principal companhia a actuar nos "Rios de Guiné", graças ao alvará secreto de 28 de Novembro de 1757, que lhe concedeu o exclusivo do comércio das ilhas de Cabo Verde e costa da Guiné. Com grandes interesses nas ilhas de Cabo Verde (a urzela, os panos de algodão) e na zona dos "Rios de Guiné", instalou bases em quase todas as ilhas do arquipélago e ainda em Bissau, Cacheu, Angola e Benguela. Em Cabo Verde, a companhia beneficiou de privilégios excepcionais. Após a petição de 14 de Novembro de 1757, a Junta da Administração da Companhia recebeu o governo político e militar das ilhas por um período de vinte anos, podendo apresentar nomes que seriam aprovados pelo rei. A Companhia assumiu assim uma jurisdição da coroa. $\mathrm{O}$ descontentamento com as condições em que actuava manifestou-se logo em 1761, face ao aumento dos preços dos produtos vendidos e ao controlo mais apertado da navegação estrangeira, legal ou ilícita. No contexto de uma "economia de favores", a Companhia Geral do Grão-Pará e Maranhão recebeu amplos privilégios, mas não parece ter cumprido as obrigações devidas pela situação de exclusivo que deteve em Cabo Verde. A Companhia Geral do Grão-Pará e Maranhão dedicou-se essencialmente ao tráfico esclavagista, mas exportou também outros produtos cabo-verdianos e da costa africana (urzela, cera, marfim e panos de algodão). Contudo, não investiu nas ilhas, cuja situação económica e social colapsou, um quadro agravado pela fome de $1773-1776^{76}$. No geral, a acção da companhia não contribuiu para recuperar a posição que os Portugueses haviam detido no passado, nem para minimizar os efeitos da crise económica e comercial em Cabo Verde. No final de Setecentos, os estrangeiros, nomeadamente os Ingleses, continuavam em força na região dos "Rios de Guiné77".

76 - Cf. CARREIRA, António. As Companhias Pombalinas de Grão-Pará e Maranhão e Pernambuco e Paraíba. Lisboa: Editorial Presença, 1983 [edição original: 1969], p. 4345, 252-271 e 272-277; BALENO, Ilídio. Reconversão do comércio externo em tempo de crise ....

77 - Cf. CARREIRA, António. As Companhias Pombalinas .... p. $52-56$ e, do mesmo autor, Notas sobre o tráfico português de escravos. $2^{\mathrm{a}}$ ed., revista, Lisboa: Universidade Nova de Lisboa, Faculdade de Ciências Sociais e Humanas, 1983 [edição original: 1978], p. 64; MONTEIRO, Fernando Amaro e ROCHA, Teresa Vázquez. A Guiné do século XVII ao século XIX: o testemunho dos manuscritos. Lisboa: Prefácio, 2004 [2005], p. 104-105. 
Por outro lado, não podemos esquecer que, mais ainda do que no caso dos Açores, os condicionalismos físicos que afectavam o exercício do poder por parte dos oficiais régios e que, em Cabo Verde, mas também mais ao sul, nas ilhas do Golfo da Guiné, contribuíram de forma determinante para o reforço do poder e autonomia da câmara da Ribeira Grande, em Santiago, mas também do da Povoação, em São Tomé. Nesta ilha, a coroa concedeu à câmara, em 1548, o privilégio de suceder no governo da ilha, na ausência dos representantes do poder central, corregedores ou governadores. Em Santiago, nos séculos XVII e XVIII, também a câmara da Ribeira Grande assumiu interinamente o governo da ilha por diversas ocasiões, geralmente após a morte dos governadores e enquanto não chegava um novo representante do longínquo poder central. Toda esta situação aumentava a capacidade de resistência dos concelhos aos agentes régios, tendo-se mesmo verificado, em ambos os arquipélagos, a deposição e prisão de governadores, nos séculos XVII e XVIII. Este quadro só se alteraria, pelo menos formalmente, no reinado de D. José I, com o decreto de 12 de Dezembro de 1770, de âmbito geral, que excluía as câmaras da sucessão no governo das ilhas ${ }^{78}$. Tal não impediu, contudo, que os "filhos da terra" continuassem a dominar a política local e a resistir à jurisdição dos governadores e ouvidores que eram enviados do reino.

No Atlântico Sul, na costa ocidental africana, a presença portuguesa em Angola em meados do século XVIII não ocupava todo o litoral entre o rio Loge e Benguela e, no hinterland, assentava numa magra rede de presídios instalados junto aos cursos de água, rede que não garantia o domínio efectivo sobre as regiões a controlar, quer pelo comportamento dos capitães-mores, quer pela resistência dos sobas. Com efeito, entre o final do século XVI e o último quartel do século XX, a situação em Angola caracterizar-se-ia sempre por uma guerra endémica, sustentada com o apoio de alguns sobas, e as dificuldades de penetração no hinterland an-

78 - Cf. BARCELOS, Christiano José de Senna. Subsidios para a Historia de Cabo Verde e Guiné. Lisboa: Academia Real das Sciencias de Lisboa, 1905, p. 50, parte III; NEVES, Carlos Agostinho das. S. Tomé e Príncipe na segunda metade do séc. XVIII. Funchal-Lisboa: Secretaria Regional do Turismo, Cultura e Emigração/Centro de Estudos de História do Atlântico-Instituto de História de Além-Mar, 1989, p. 45 e 50. 
golano manter-se-ão uma constante. Não admira, pois, que a estrutura administrativa portuguesa no território assentasse na organização militar dos presídios, justificando plenamente a afirmação de Orlando Ribeiro segundo a qual Luanda e Benguela eram "feitorias em país inimigo ${ }^{79}$ ". Por outro lado, a economia da possessão portuguesa dependia do comércio esclavagista, sobretudo o que era realizado com o Brasil, não existindo uma "economia de plantação".

O reino de Angola, no entanto, não ficou à margem das transformações que se tentou introduzir, com maior ou menor sucesso, na administração do império e, em particular, no espaço atlântico, pelo que os anos centrais e finais do reinado josefino foram, naquele domínio, um tempo de implementação de projectos e reformas ambiciosas. Alguns dos projectos eram antigos, relacionando-se com as vias de comunicação e a desejada ligação com Moçambique. Dada a importância de Angola no fornecimento de escravos ao Brasil e a outros mercados, depois da criação das duas companhias monopolistas e no seguimento do alvará de 1758, Sebastião José de Carvalho e Melo, já conde de Oeiras, apresentou ao rei um parecer de sua lavra no qual expôs o seu projecto para "restituir" a agricultura, a navegação e o comércio de Angola. Afirmando que o reino de Angola podia vir a ser um império, defendeu uma política de colonização que faria desta conquista uma colónia de povoamento. Apostando na territorialização da presença portuguesa em Angola e na politização do sertão, o conde de Oeiras esperava assim obter uma melhor integração das conquistas atlânticas e, por essa via, maiores dividendos para a monarquia portuguesa. O projecto era grandioso, mas megalómano e, no fundo, impraticáve ${ }^{80}$.

Se D. António de Vasconcelos, homem da confiança de Sebastião José, terá sido o primeiro governador "pombalino" de Angola - che-

79 - Cf. RIBEIRO, Orlando. A colonização de Angola e o seu fracasso. Lisboa: Imprensa Nacional-Casa da Moeda, 1981, p. 325.

80 - Cf. SANTOS, Catarina Madeira. Um governo "polido” para Angola. Reconfigurar dispositivos de domínio (1750-c.1800). Tese (Doutoramento em História) - Faculdade de Ciências Sociais e Humanas da Universidade Nova de Lisboa. Lisboa, 2005, policopiado, p. 44-66 e 135-183. A autora refere o carácter "impraticável” do projecto na p. 150. 
gou a 4 de Outubro de 1758 -, salientou-se pela sua acção D. Francisco Inocêncio de Sousa Coutinho (1764-1772), que alguns autores consideraram ter sido "o governador pombalino por excelência de Angola ${ }^{81 "}$ ". O governador estava ligado a Sebastião José de Carvalho e Melo por laços de parentesco espiritual - o conde de Oeiras era padrinho de três filhos de Francisco Inocêncio -, o que terá influenciado a sua nomeação para o governo de Angola ${ }^{82}$. Durante o seu governo, aplicou o reportório de medidas que encontramos associadas à visão pombalina para a conquista. A exploração geográfica conheceu um grande impulso, tanto para leste, como para sul, sobretudo em Benguela, apontando ao planalto de Huíla, e fundou-se Novo Redondo (1769), como ponto de apoio na ligação entre Angola e Benguela, e as capitanias-mores de Bié e do Bailundo (1770). No plano da economia, o governador organizou a exploração do sal em Benguela; projectou e montou uma fábrica de ferro em Nova Oeiras, recorrendo à mão de obra de ferreiros e fundidores locais, empreendimento que os seus sucessores deixaram cair em desuso, e uma outra de solas, atanados e couros em Benguela, de modo a valorizar a pecuária da região; tentou desenvolver a agricultura, publicando um bando em que ameaçava expropriar todos aqueles que tivessem terras por cultivar e procurando incrementar a cultura da urzela e do anil; estabeleceu novas feiras; e tentou uma exploração da riqueza mineral de Angola ${ }^{83}$. De igual modo, durante este governo, foi implementado o funcionamento do Terreiro Público, criado por carta régia de 13 de Novembro de 1761 a partir de proposta de Sebastião José de Carvalho e Melo. A sua direcção cabia ao Senado da Câmara de Luanda e destinava-se a articular o hinterland angolano e a economia atlântica. A função do Terreiro Público era dirigir e fiscalizar a distribuição e venda dos produtos agrícolas mais importantes (farinha de mandioca, feijão e milho), base da alimentação em Luanda,

81 - Cf. REGO, António da Silva. O Ultramar Português no século XVIII. Lisboa: Agência-Geral do Ultramar, 1970, p. 163.

82 - Cf. SILVA, Andrée Mansuy-Diniz. Portrait d'un homme d'État: ..., vol. I: Les années de formation 1755-1796. p. 33.

83 - Cf. DELGADO, Ralph. O Governo de Sousa Coutinho em Angola. Stvdia. Lisboa: n. ${ }^{\circ}$ 6, p. 19-56, Julho 1960, n. ${ }^{\circ}$ 7, p. 49-86, Janeiro 1961, e n. ${ }^{\circ}$ 10, p. 7-47, Julho 1962; CORTESÃO, Jaime. O Ultramar Português depois da Restauração. Lisboa: Portugália Editora, 1971, p. 291-299. 
mas igualmente alimento dos escravos embarcados para o Brasil. Convirá ainda referir que uma parte do soldo dos militares era pago em farinha de mandioca, o que, desde logo, justificava o interesse da Fazenda Real em controlar os preços dos produtos ${ }^{84}$.

De regresso ao reino, o governador fez uma autoavaliação muito positiva do seu desempenho em carta dirigida ao filho, Rodrigo. O Secretário de Estado e já marquês de Pombal, aliás, felicitara-o pelo "completo acerto" com que actuara ao serviço da monarquia ${ }^{85}$. Angola viveu assim um curto período de fomento e investimento reformista. Como em outras partes do império, nesta segunda metade do século XVIII estaríamos a assistir à aplicação em Angola de um novo paradigma, norteado pela noção de "polícia" e pelo ideal da "administração activa". Os sucessores de D. Francisco Inocêncio, porém, não seguiram todas as suas linhas de actuação e, pontualmente, ignoraram mesmo os projectos daquele governador, como foi o caso de D. António de Lencastre (1772-1779), que não se interessou pela fábrica de ferro. Afinal, se continuassem a promover os resultados da actuação voluntarista de D. Francisco Inocêncio estariam eventualmente a contribuir para a maior glória daquele, mas não da sua. No final do século, o governador D. Miguel António de Melo escreveria acerca da incapacidade portuguesa de controlar o comércio na região da barra dos rios Loge e Dande que

desde que, em cumprimento do aviso de 12 de Agosto de 1791, foi demolido o reduto (a que chamamos com nome pomposo Fortaleza) de S. João do Loge e as outras disposições do mesmo aviso se executaram, os ingleses levam bastante marfim, não pouca cera, os melhores escravos, ficando para nós principalmente destes os refugos que deixam ${ }^{86}$.

Podemos assim concluir lembrando algumas das ideias presentes no estudo de Catarina Madeira Santos, quando afirmou que o episódio de 84 - Cf. VENÂNCIO, José Carlos. A Economia de Luanda e hinterland no século XVIII. Um estudo de Sociologia Histórica. Lisboa: Editorial Estampa, 1996, p. 63-67.

85 - Cf. SILVA, Andrée Mansuy-Diniz. Portrait d'un homme d'État: ..., vol. I: Les années de formation 1755-1796. p. 35 e 316-317.

86 - Cf. DIAS, Gastão Sousa. Os portugueses em Angola. Lisboa: Agência-Geral do Ultramar, 1959, p. 299-300. 
Cabinda, na década de 1780, constituiu a ilustração da "impossibilidade de manter um império tão extenso suportado em meios de imposição de soberania débeis" e que existiu uma "distância entre o projecto político imaginado em Lisboa e a acção no terreno ${ }^{87 "}$.

Na margem americana do Atlântico Sul, as Américas portuguesas também foram tocadas por projectos de mudança, embora neste caso as generalizações sejam ainda mais perigosas, pois a aplicação de uma grelha de interpretação uniforme a partir de alguns casos melhor conhecidos não dá conta da diversidade geográfica nem dos distintos ritmos de integração territorial a partir dos dois principais clusters ou "arquipélagos" de colonização ${ }^{88}$. Tendo presentes estas condicionantes, vejamos as conclusões a que chegaram alguns autores.

Em relação ao Brasil, Nuno Gonçalo Monteiro concluiu que, no geral, o governo do Estado não conheceu qualquer mudança digna de registo durante este período, pelo menos nada que seja comparável às reformas globais introduzidas na América bourbónica pelo Secretário de Estado José de Gálvez ${ }^{89}$. De resto, foi a norte, no Estado do Grão-Pará e Maranhão, que mais se sentiu a intervenção do centro político, embora aquele historiador afirme: "O balanço final desse processo está longe de se poder considerar um êxito absoluto".

Terá sido nas questões fiscais e económicas que a legislação destes anos mais se fez sentir. No entanto, os resultados ficaram aquém do 87 - Cf. SANTOS, Catarina Madeira. Um governo "polido” para Angola. .... p. 316322, maxime p. 321 para a citação, e p. 386.

88 - Veja-se a análise da geopolítica portuguesa na América do Sul, distinguindo os dois espaços, em MARTINIĖRE, Guy. A implantação das estruturas de Portugal na América (1620-1750). In: MAURO, Frédéric (coord.). O Império Luso-Brasileiro (1620-1750), Nova História da Expansão Portuguesa, dir. Joel Serrão e A. H. de Oliveira Marques. Lisboa, Editorial Estampa, 1991, p. 91-261, vol. VII.

89 - Cf. MONTEIRO, Nuno Gonçalo. Pombal's Government: Between SeventeenthCentury Valido and Enlightened Models. In: PAQUETTE, Gabriel (ed.). Enlightened Reform in Southern Europe and its Atlantic Colonies, .... p. 321-338; MONTEIRO, Nuno Gonçalo. As reformas na monarquia pluricontinental portuguesa: de Pombal a dom Rodrigo de Sousa Coutinho. In: FRAGOSO, João e GOUVÊA, Maria de Fátima (org.). $O$ Brasil Colonial, vol. 3 (ca. 1720-ca. 1821). Rio de Janeiro: Civilização Brasileira, 2014, p. 111-156, maxime p. 136 para a citação. 
pretendido, no reino e no império. A propósito da constituição do Erário Régio e da implementação de novas regras de funcionamento da administração régia, mormente pela imposição de uma hierarquia entre o Erário Régio e as Juntas da Fazenda, Miguel Dantas da Cruz afirmou que o projecto do Secretário de Estado encontrou grandes resistências e que se registaram vários problemas relacionados com as arrematações de contratos e com a gestão de recursos destinados ao esforço de guerra. Se é verdade que o Erário Régio e o sistema de Juntas da Fazenda continuou para além do final do reinado josefino, não é menos certo que a administração fiscal da coroa revelou uma evidente falta de eficácia e que elites locais disso se aproveitaram ${ }^{90}$.

De igual modo, Angelo Alves Carrara concluiu pelo falhanço das projectadas reformas introduzidas no Estado do Brasil. Ao estudar a fiscalidade e, em concreto, o reformismo fiscal pombalino, este autor afirmou:

Se levar-se em consideração estritamente o critério da eficácia tributária da[s] medidas fiscais pombalinas - isto é, a "regular e exata arrecadação das rendas que constituem o erário público", como propunha o alvará de 1761, elas resultaram num retumbante fracaso ${ }^{91}$.

E, mais adiante, acrescenta:

Algo que ainda não foi objeto de análise consistente pela historiografia é a contradição entre o propalado êxito da política econômica pombalina no Estado do Maranhão e Grão Pará, de um lado, ao lado de um fracasso fiscal estrondoso. Este fato obriga a uma investigação detida tanto sobre os agentes diretamente envolvidos nos negócios da Companhia de Comércio quanto sobre o funcionamento da administração fazendária no Pará ${ }^{2}$.

3. Em 1777, após a morte de D. José I, não teve lugar uma crise sucessória e a continuidade da monarquia - e, portanto, do poder monár-

90 - Cf. CRUZ, Miguel Dantas da. Pombal e o Império Atlântico: impactos políticos da criação do Erário Régio. Tempo. Niterói: vol. 20, 2014 [DOI: 10.1590/TEM-1980542X-2014203621].

91 - Cf. CARRARA, Angelo Alves. O reformismo fiscal pombalino no Brasil. Historia Caribe. Vol. XI, n. ${ }^{\circ}$ 29, p. 83-111, Julho-Dezembro 2016, maxime p. 104 para a citação.

92 - Idem, p. 106. 
quico - não foi posta em causa por meio de uma "revisão" da história e da prática política recentes. Deste modo, não houve um regresso ao passado e o processo a que se chamou "Viradeira" manifestou-se sobretudo ao nível da primeira nobreza de corte ${ }^{93}$. No entanto, nos anos subsequentes a 1777, assistiu-se a uma certa reorientação da política anterior. O facto de não se ter registado uma resistência às mudanças ou às reabilitações então operadas, o que sugere, de forma clara, que não existia um "partido pombalino", tal como assinalaram Jorge Pedreira e Fernando Dores Costa ${ }^{94}$.

Após a longa experiência da governação de Sebastião José de Carvalho e Melo no reinado anterior e o seu carácter excepcional, o período mariano parece ter correspondido a um retorno a uma situação de equilíbrio tradicional do poder. Todavia, importa não perder de vista que algumas linhas de força definidas durante o reinado josefino permaneceram actuantes. As Secretarias de Estado continuaram a ser os centros de decisão política por excelência e os titulares dos postos-chave exerceram o poder durante um largo número de anos, tal e qual o fizera Sebastião José de Carvalho e Melo, de resto no seguimento de uma tendência que se desenhara na primeira metade do século XVIII. Dois dos ministros em exercício permaneceram no seu cargo durante o reinado de D. Maria I: Martinho de Melo e Castro, Secretário de Estado da Marinha e Ultramar desde 1770 e que serviu até à sua morte, em 1795, e Aires de Sá e Melo, Secretário de Estado dos Negócios Estrangeiros e da Guerra desde $1775^{95}$. Ambos asseguraram a transição entre os reinados de D. José e D. Maria I e o prolongamento de alguns dos fios condutores das políticas interna e externa da monarquia e do governo das conquistas, com destaque para Martinho de Melo e Castro. Esta mesma ideia, de resto, foi exposta na viragem do século em obra originalmente composta em Inglês, vertida

93 - Cf. MONTEIRO, Nuno Gonçalo. Pombal e a aristocracia. Camões. Revista de Letras e Culturas Lusófonas. Lisboa: n. ${ }^{\circ}$ 15-16, Janeiro-Junho 2004: Marquês de Pombal, p. 34-41.

94 - Cf. PEDREIRA, Jorge e COSTA, Fernando Dores. D. João VI. Lisboa: Círculo de Leitores, 2006, p. 31.

95 - Sobre Martinho de Melo e Castro, ver BEIRÃO, Caetano. D. Maria I (1777-1792). Subsidios para a revisão da história do seu reinado. Lisboa: Empresa Nacional de Publicidade, 1934, p. 86-89. 
para Francês e, depois, traduzida em Português e anotada pelo célebre António de Morais Silva e editada com o patrocínio da Academia Real das Ciências. Ao serem apresentadas as nomeações efectuadas pela rainha, refere-se que D. Maria procurou "preencher as vistas, e as disposições d'ElRei seu Pai", aperfeiçoar a forma do governo e elevar à perfeição "o quadro magnifico do Imperio Lusitano [que] tinha sido deixado em esboço". Sublinhava-se, assim, a continuidade, por um lado, e os avanços do reinado, por outro ${ }^{96}$.

Contudo, no que ao império se refere, certo é que algumas das instituições ou reformas mais emblemáticas do reinado josefino, que terão sido obra ou obtido o apoio de Sebastião José, foram extintas ou revogadas quase de imediato. No espaço atlântico, estiveram neste caso as duas companhias majestáticas. A Companhia Geral do Grão-Pará e Maranhão foi extinta em 1778 e a decisão saudada em Lisboa com um Te Deum; quanto à Companhia Geral de Pernambuco e Paraíba, sobreviveu uns meses mais, sendo extinta em 1779 e os seus navios colocados ao serviço da coroa na navegação para a Ásia ${ }^{97}$. As companhias monopolistas criadas à sombra do proteccionismo mercantilista não estavam de acordo com as novas ideias que emergiam - em 1776, Adam Smith dera à estampa a sua opus magnum, na qual criticava esta política -, não obstante ser essa uma solução que, em Portugal, foi defendida ainda no século XIX ${ }^{98}$.

4. Numa avaliação da acção governativa de Sebastião José de Carvalho e Melo, podemos concluir que, no balanço entre objectivos per-

96 - Cf. Historia de Portugal composta em Inglez por huma Sociedade de Litteratos, trasladada em vulgar com as addições da versão franceza, e notas do traductor Portuguez, Antonio de Moraes Silva, Natural do Rio de Janeiro. E agora novamente emendada, e accrescentada com varias Notas, e com o resumo do Reinado da Rainha N. S. até o anno de 1800.. Lisboa: na Typografia da Academia Real das Sciencias de Lisboa, Tomo IV, 1802, p. 82-83.

97 - Cf. BEIRÃO, Caetano. D. Maria I ..., p. 130-131.

98 - Cf. CUNHA, João Manuel Teles e. Economia e finanças. A rede económica do Estado da Índia (1660-1750). In: LOPES, Maria de Jesus dos Mártires (coord.). O Império Oriental (1660-1820), Nova História da Expansão Portuguesa, dir. Joel Serrão e A. H. de Oliveira Marques. Lisboa: Editorial Estampa, 2006, p. 162-338, vol. V, tomo I, maxime p. 337; CUNHA, João Manuel Teles e. A Carreira da Índia e Goa - apogeu e declínio crepusculares (1760-1835). In: ibidem, p. 380-449, maxime p. 415. 
seguidos e resultados alcançados, nem todas as reformas operadas pelo ministro de D. José se manifestaram de imediato ou produziram os efeitos pretendidos pelo legislador. Se, como defendem alguns autores, existiu um "projecto pombalino" para as sociedades portuguesas, a do reino e as do império, importa saber como é que a monarquia o procurou materializar, quem foram os seus agentes, quais as resistências que encontrou, qual o seu alcance real. Ao avaliarmos o papel das instituições na produção da mudança social, constatamos a centralidade da legislação da monarquia ao nível do ordenamento social e das relações de poder no Antigo Regime. Se os textos legislativos estabeleciam as coordenadas de legitimidade que deviam balizar a actuação dos oficiais régios e o comportamento dos vassalos, uma avaliação do papel das instituições na produção da mudança social reconhecerá que o resultado social se caracterizou por um amplo leque de situações, que exigem ser estudadas em termos de uma "microfísica do poder", isto é, da interacção entre os actores institucionais e sociais e da importância dos contextos locais e das redes interpessoais nos jogos de poder e nas práticas de dominação concretas.

A eficácia da legislação e das instituições da monarquia, aliás, seria maior no centro do que nas periferias. Os exemplos aqui apresentados de forma telegráfica colocam-nos perante dois grandes tipos de obstáculos que os centros políticos enfrentavam: os geográficos (distância, descontinuidade territorial, extensão) e os políticos e sociais (resistência das populações nativas ou das elites locais, estrutura tradicional do poder). Em relação aos primeiros, lembremos as palavras de D. Francisco Inocêncio de Sousa Coutinho a propósito de Angola, quando era embaixador na corte espanhola: "Não hé possivel, que hum menistro d'Estado possa saber tudo, e muito mais de regioens tam distantes ${ }^{99}$ ". Algo semelhante havia dito também o conde da Ega, Manuel de Saldanha de Albuquerque, vice-rei da Índia (1758-1765), acerca do desconhecimento da Ásia por parte do centro político ${ }^{100}$. E recordemos ainda o espanto do $4 .^{\circ}$ morgado de

99 - Cf. SILVA, Andrée Mansuy-Diniz. Portrait d'un homme d'État: ..., vol. I: Les années de formation 1755-1796, p. 363-366, maxime p. 364.

100 - Cf. RODRIGUES, José Damião. Um tempo de ruptura? (1750-1778). p. 289290. 
Mateus, D. Luís António de Sousa Botelho Mourão, governador de São Paulo, que, nas suas cartas à esposa, dava conta da desmesura do território e das grandes distâncias a percorrer ${ }^{101}$.

Por outro lado, situadas na longa duração, as reformas "pombalinas" adquirem contornos distintos de propostas mais inovadoras, o que não nos deve surpreender. Afinal, o repertório de medidas e os dispositivos institucionais à disposição da monarquia portuguesa eram mais tradicionais do que inovadores e a implementação das reformas não se fez sem oposição e resistências, por vezes violentas ${ }^{102}$. As inércias e resistências da sociedade corporativa tradicional funcionaram como factores de bloqueio ou de resistência às reformas emanadas do centro político, que podiam abalar as bases da autoridade das elites locais ou introduzir mecanismos mais rigorosos de cobrança fiscal ou de alistamento. Por esse motivo, nos territórios da monarquia portuguesa, como nos de outras monarquias, a coroa e os seus oficiais foram forçados a negociar com os grupos dominantes que constituíam a cúspide da ordem política e social. E, por esse motivo, entre outros, as monarquias não conseguiram atingir plenamente os objectivos que, idealmente, perseguiam. Seria apenas com o Liberalismo que, pouco a pouco, a modernidade política penetraria em Portugal, um cenário que, cremos, se repetiu em ambas as margens do mundo lusófono.

Texto apresentado em dezembro de 2020. Aprovado para publicação em abril de 2021.

101 - Cf. BELlotTO, Heloísa Liberalli. Nem o Tempo Nem a Distância. Correspondência entre o 4. ${ }^{\circ}$ Morgado de Mateus e sua mulher, D. Leonor de Portugal (1757-1798). Lisboa: Alêtheia Editores, 2007, carta de Santos, de 25 de Dezembro de 1765, p. 216-218, maxime p. 216.

102 - Sobre esta questão e num quadro de Antigo Regime, ver RICCARDO, Rosolino e MARIA, Novella Borghetti. Vices tyranniques. Résistance au monopole, idéologie et marché à l'aube de la modernité. Annales. Histoire, Sciences Sociales. Paris: $68^{\mathrm{e}}$ année, 2013/3, p. 793-819. 